\title{
Results of Submerged Sediment Core Sampling and Analysis on Par Pond, Pond C, and L Lake: July 1995 (U)
}

by

J. W. Koch

Westinghouse Savannah River Company

Savannah River Site

Aiken, South Carolina 29808

F. D. Martin

G. P. Friday

DOE Contract No. DE-AC09-89SR18035

This paper was prepared in connection with work done under the above contract number with the U. S.

Department of Energy. By acceptance of this paper, the publisher and/or recipient acknowledges the U.S. Government's right to retain a nonexclusive, royalty-free license in and to any copyright covering this paper, along with the right to reproduce and to authorize others to reproduce all or part of the copyrighted paper. 


\section{DISCLAIMER}

This report was prepared as an account of work sponsored by an agency of the United States Government. Neither the United States Government nor any agency thereof, nor any of their employees, makes any warranty, express or implied, or assumes any legal liability or responsibility for the accuracy, completeness, or usefulness of any information, apparatus, product, or process disclosed, or represents that its use would not infringe privately owned rights. Reference herein to any specific commercial product, process, or service by trade name, trademark, manufacturer, or otherwise does not necessarily constitute or imply its endorsement, recommendation, or favoring by the United States Government or any agency thereof. The views and opinions of authors expressed herein do not necessarily state or reflect those of the United States Government or any agency thereof.

This report has been reproduced directly from the best available copy.

Available to DOE and DOE contractors from the Office of Scientific and Technical Information, P.O. Box 62, Oak Ridge, TN 37831; prices available from (615) 576-8401.

Available to the public from the National Technical Information Service, U.S. Department of Commerce; 5285 Port Royal Road, Springfield, VA 22161. 
DISClaAMIER

Portions of this document may be illegible in electronic image products. Images are produced from the best avaliable original document. 


\title{
Results of Submerged Sediment Core Sampling and Analysis on Par Pond, Pond C,
} and L Lake: July 1995 (U)

\author{
J. W. Koch II, F. D. Martin, and G. P. Friday
}

Westinghouse Savannah River Company

Savannah River Site

Aiken, SC 29808

June 1996

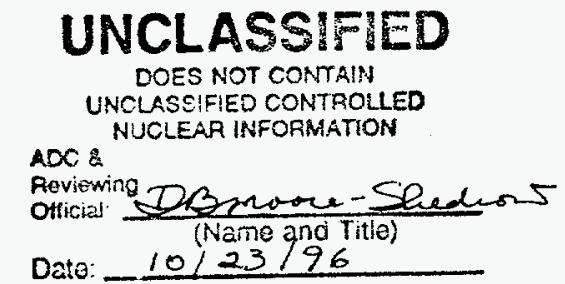

The information contained in this report was developed during the course of work under Contract No. DE-AC0989SR18035 with the U.S. Department of Energy. 


\section{Disclaimer}

This report was prepared as an account of work sponsored by an agency of the United States Government. Neither the United States Government nor any agency thereof, nor any of their employees, makes any warranty, expressed or implied, or assumes any legal liability or responsibility for the accuracy, completeness, or usefulness of any information, apparatus, product, or process disclosed, or represents that its use would not infringe privately owned rights. Reference herein to any specific commercial product, process, or service by trade name, trademark, manufacturer, or otherwise does not necessarily constitute or imply its endorsement, recommendation, or favoring by the United States Government or any agency thereof. The views and opinions of authors expressed herein do not necessarily state or reflect those of the United States Government or any agency thereof. 
Abstract .1

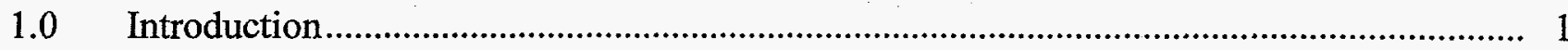

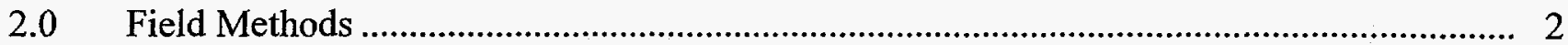

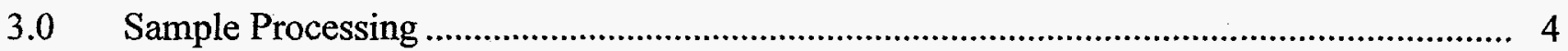

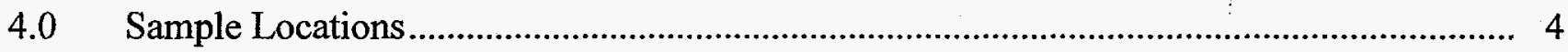

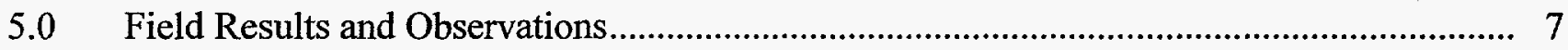

5.1 Lacustrine/Alluvial Channel Sediment Thickness ................................................. 7

5.1.1 Par Pond .................................................................................. 7

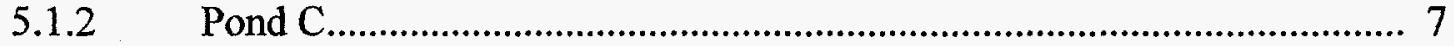

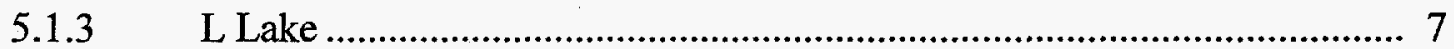

5.1.4 Streams and Lake Marion .................................................................. 10

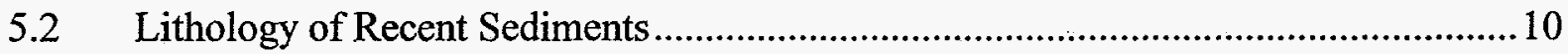

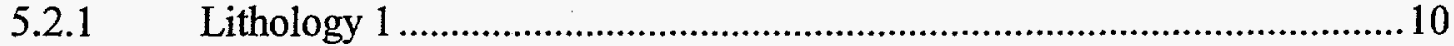

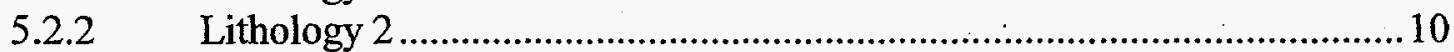

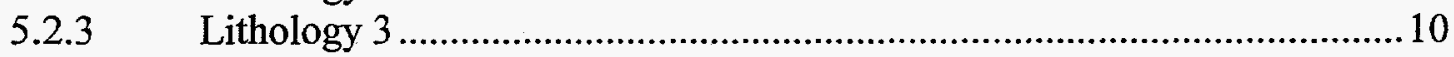

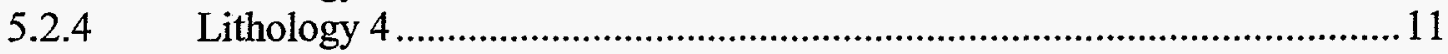

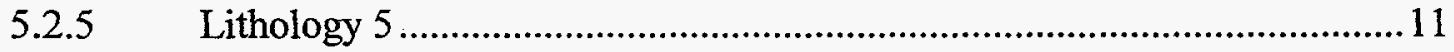

6.0 Analytical Results 12

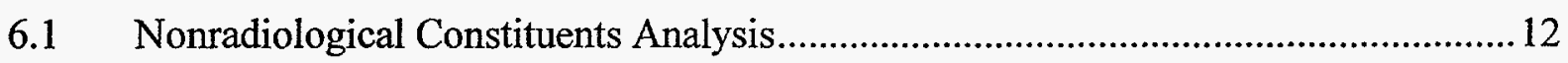

6.1.1 Data Analysis ...................................................................................12

6.1.2 Comparison of Results with EPA Region IV

Screening Criteria .................................................................................. 12

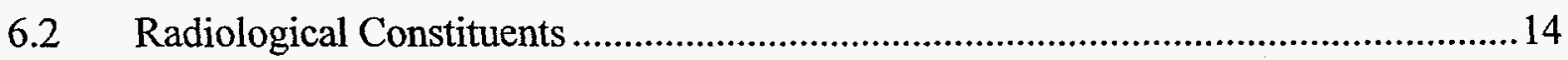

6.2.1 Data Analysis ...................................................................................... 14

6.2.2 Comparison of Isotopes in Par Pond and

L Lake with Background Locations ...........................................................17

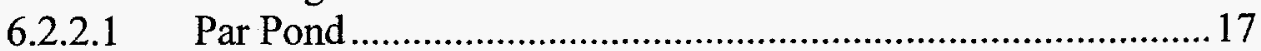

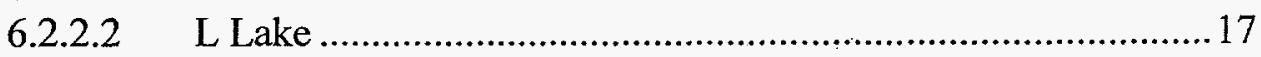

6.2.3 Comparison of Specific Isotope Activity ………......................................17

6.2.3.1 Cesium-137 …..............................................................27

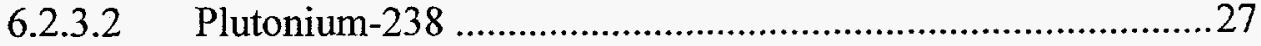

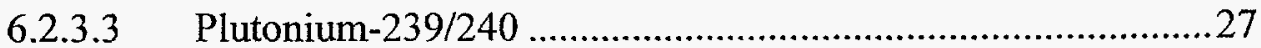

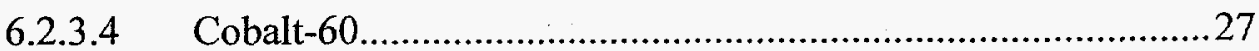

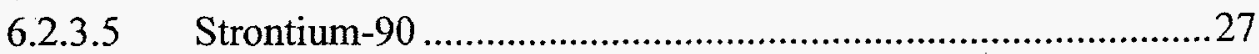

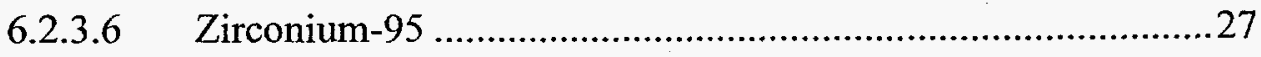




\section{Table of Contents (continued)}

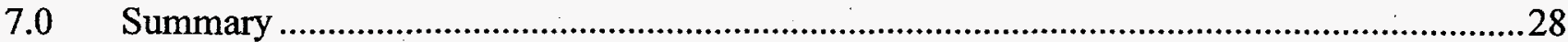

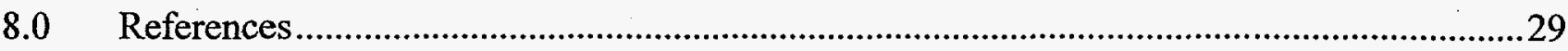




\section{List of Figures}

Figure 1. Sample locations for SRS sediment cores

\section{List of Tables}

Table 1. Universal Transverse Mercator coordinates for all sediment core locations in Par Pond, Pond C, L Lake, Meyer's Branch, Mill Creek, Tinker Creek, and Lake Marion.

Table 2. Description of sediment cores from Par Pond, Pond C, L Lake, Meyer's Branch, Mill Creek, Tinker Creek, and Lake Marion. 1995 ..........................8

Table 3. EPA Region IV screening criteria for potential contaminants of concern ................13

Table 4. Results of a comparison of nonradiological contaminants in Par Pond core segments with EPA Region IV potential contaminants of concern screening values.

Table 5. Results of a comparison of nonradiological contaminants in L-Lake core segments with EPA Region IV potential contaminants of concern screening values.

Table 6. Results of a comparison of nonradiological contaminants in background locations core segments with EPA Region IV potential contaminants of concern screening values.

Table 7. Results of Kruskall-Wallis nonparametric tests of concentrations

of radioisotopes in Par Pond compared to all background locations.

Table 8. Results of Kruskall-Wallis nonparametric tests of concentrations

of radioisotopes in L Lake compared to all background locations

Table 9. General descriptive statistics for radioactive constituents $(\mathrm{pCi} / \mathrm{g})$ in

Par Pond sediment cores.

Table 10. General descriptive statistics for radioactive constituents $(\mathrm{pCi} / \mathrm{g})$ in

Pond $\mathrm{C}$ sediment cores

Table 11. General descriptive statistics for radioactive constituents ( $\mathrm{pCi} / \mathrm{g}$ ) in

L-Lake sediment cores

Table 12. General descriptive statistics for radioactive constituents (pCi/g) in Meyer's Branch sediment cores

Table 13. General descriptive statistics for radioactive constituents $(\mathrm{pCi} / \mathrm{g})$ in Mill Creek sediment cores. 
Table 14. General descriptive statistics for radioactive constituents ( $(\mathrm{pCi} / \mathrm{g})$ in Tinker Creek sediment cores

Table 15. General descriptive statistics for radioactive constituents (pCi/g) in Lake Marion sediment cores.

\section{List of Appendices}

Appendix A Sample Identification Key for Analytical Results

Appendix B Analyte List (from Nichols 1995) 


\title{
Results of Submerged Sediment Core Sampling and Analysis on Par Pond, Pond C, and L Lake: July 1995
}

\author{
J. W. Koch II, F. D. Martin, and G. P. Friday
}

\begin{abstract}
Sediment cores from shallow and deep water locations in Par Pond, Pond C, and L Lake were collected and analyzed in $\mathbf{1 9 9 5}$ for radioactive and nonradioactive constituents. This core analysis was conducted to develop a defensible characterization of contaminants found in the sediments of Par Pond, Pond C, and L Lake.
\end{abstract}

Mercury was the only nonradiological constituent with a nonestimated quantity that was detected above the U.S Environmental Protection Agency Region IV potential contaminants of concern screening criteria. It was detected at a depth of 0.3-0.6 meters (1.0-2.0 feet) at one location in $\mathrm{L}$ Lake.

Cesium-137, promethium-146, plutonium-238, and zirconium-95 had significantly higher concentrations in Par Pond sediments than in sediments from the reference sites. Cobalt-60, cesium137 , plutonium-238, plutonium-239/240, and strontium- 90 had significantly higher concentrations in L-Lake sediments than sediments from the reference sites.

\subsection{Introduction}

In July 1995, Westinghouse Savannah River Company (WSRC), Savannah River Technology Center Environmental Sciences Section conducted sediment core sampling in Par Pond, Pond C, and L Lake to characterize the contaminants in various layers of sediment. Sediment cores were taken from 12 locations in Par Pond, 8 locations in L Lake, and 2 locations in Pond C. In addition, cores were taken from five background locations. Four of the background locations were at streams on the Savannah River Site (SRS), and one was in Lake Marion, SC.

In 1958, the headwaters of Lower Three Runs were impounded with an earthen embankment to form Par Pond. Par Pond served as a recirculating reservoir for P and R Reactors through 1963 and for $\mathrm{P}$ Reactor alone until 1988. Pond $\mathrm{C}$ is separated from Par Pond by an earthen dam that keeps the water level in Pond C approximately 0.3 meters ([m]1 foot) above normal pool in Par Pond. It was separated from Par Pond to increase cooling efficiency during reactor operations. During the course of operations, the reactors released relatively small quantities of radionuclides into Par Pond. Predominant radionuclides included cesium-137 and tritium. Cesium-134, cobalt-60, and plutonium isotopes were released in much smaller quantities.

In order to maintain constant levels in the reservoir, Par Pond received makeup water pumped from the Savannah River to replace what was lost by evaporation and what was diverted to Lower Three Runs. Mercury from the Savannah River was introduced into Par Pond.

In 1991, a depression was discovered on the downstream slope of the Par Pond dam. To ensure the safety of residents downstream in the event of a dam failure, Par Pond was lowered from approximately $61 \mathrm{~m}$ (200 feet) above mean sea level (MSL) to approximately $55 \mathrm{~m}$ (181 feet) above MSL. The drop in water level exposed sediments contaminated with radioactive isotopes and mercury. Because Par Pond was listed as a potential Comprehensive Environmental Response, 
Compensation, and Liability Act (CERCLA) site in the SRS Federal Facilities Agreement, the U.S. Department of Energy (DOE) and the U.S. Environmental Protection Agency (EPA) considered the drawdown a removal action.

The Par Pond CERCLA unit was defined as the exposed sediments in Par Pond between approximately $55 \mathrm{~m}$ (181 feet) and approximately $61 \mathrm{~m}$ (200 feet) above MSL. It included the exposed sediments in Pond $\mathrm{C}$ between approximately $59 \mathrm{~m}$ (195 feet) and approximately $61 \mathrm{~m}(201$ feet) above MSL. The sediments that remained under water after the drawdown were not part of the CERCLA unit. The lake was refilled in late 1995, after the dam was repaired.

L Lake was constructed on Steel Creek in 1985 as a once-through cooling water reservoir for L Reactor. Prior to construction of $L$ Lake, $P$ Reactor had released quantities of radioisotopes into Steel Creek. Predominant radioisotopes in the Steel Creek basin are similar to those found in Par Pond and Pond $\mathrm{C}$ and include cesium-137 and tritium. Cesium-134, cobalt-60, and plutonium isotopes are present, but in much smaller quantities.

L Lake receives makeup water pumped from the Savannah River to maintain its water level. Consequently, L Lake is contaminated with mercury. Without this makeup water, L Lake is expected to drain slowly because the watershed above the dam is not large enough to maintain the lake at full pool.

There are no plans to restart $L$ Reactor. Allowing $L$ Lake to drain is a cost-saving option being considered by DOE. The sediment analysis provides definitive information on the contaminants in L Lake. This information will be considered in the decision on the future of L Lake.

In response to the need for a full-scale contaminants screening study, a sampling program was established. This program was designed to develop a complete and defensible list of contaminants for Par Pond, Pond C, and L Lake and to identify all potential contaminants of concern (PCOC) in the sediments of those reservoirs. The results of the screening study will serve as the basis for future studies to determine in detail the spatial distribution and ecological effects of the contaminants.

\subsection{Field Methods}

Sediment core sampling services were contracted to Science Applications International Corporation (SAIC) with field sampling subcontracted to Athena Technologies. All sampling activities are described in detail in the SAIC field report issued to WSRC (SAIC 1995) and are summarized in this report.

Vibracoring was used to collect all samples. The vibracore machine is a gasoline-powered 8.5horsepower (hp) engine equipped with a vibrating head on a flexible steel wire. This equipment is similar to that used in the construction industry for vibrating wet concrete. Attached to the vibrating head was a clamp that closes around a 3-inch diameter, thin-walled, aluminum pipe approximately 15 feet long. The bottom of the pipe is beveled. The pipe was raised to a vertical position with the beveled end resting against the substrate. When the engine started, the vibrating head vibrated the aluminum pipe into the sediment, capturing a solid core of material.

For lake bottom sampling, the equipment was set up on a barge that served as the coring platform. The coring barge consisted of four metal panels filled with foam flotation bolted to form a platform approximately 10 feet square. In its center was a rectangular hole approximately $2-b y-4$ feet. Bolted 
to the deck and centered over the hole was a steel derrick, approximately 10 feet high, which guided the coring drill string through the platform.

The basic vibracorer described previously was modified to advance the pipe under water by attaching a check valve assembly and lengths of 2-inch diameter galvanized drill pipe with quick-connect couplings to the coring pipe. The core pipe was lowered through the barge deck, and drill pipe lengths were added until the bottom of the core pipe rested on the lake bottom. When the pipe was on the lake bottom, the length of the drill string above the water surface was measured and subtracted from the overall drill-string length to determine water depth. A second measure of water depth was taken with a depth finder. When coring began, the drill string advanced via vibration for approximately five minutes or to refusal, whichever occurred first. Normally, initial penetration occurred rapidly because the pipe was advancing through the soft, organic layers. When the denser, more cohesive layers were encountered, penetration slowed or stopped. After five minutes or when the pipe was no longer penetrating the substrate, a strap was wrapped around the drill string and a crew member used his body weight to increase the penetration and to ensure that a plug of cohesive material was in the pipe's bottom to facilitate core recovery.

Electric and manual winching was used to pull the core pipe out of the sediments and onto the barge. The check valve assembly ensured suction was maintained on the core to prevent it from sliding out of the end of the pipe.

Once on the barge deck, the core-pipe bevel was cut off, and the bottom end was labeled and capped. The check valve assembly was removed, and the water in the top of the core pipe was gently decanted at a very shallow angle. After decanting the water, the length of the core was determined. A measure of compaction was not possible, and therefore, less than $100 \%$ recovery was always attributed to core loss, not compaction. The portion of the pipe above the core was cut away and the top end of the core was labeled and capped. The core was placed inside a wooden, insulated cooler with ice.

In the streams and Lake Marion (which had near-shore sample sites only), a portable vibracorer operated by a 1.5-hp engine mounted on a backpack was used to collect the cores. The coring procedure was the same as described for the deep water samples; however, no check valve assembly was used and no drill string was necessary.

When the core pipe had advanced to refusal, the vibracorer was turned off and the vibrating head was removed from the pipe. The portion of the pipe above the top of the core was measured. The length of pipe above the stream bed also was measured. These two numbers were used to quantify sample compaction. Compaction was significant in some cores due to their coarse-grained nature and the presence of extensive voids between grains. After the measurements were taken, the empty portion of pipe was carefully filled with water so as not to disturb the sediments, and a plumber's stopper was secured in the pipe top to create a suction to maintain the core in the pipe as it was removed from the sediments. An aluminum tripod was erected directly over the core pipe, and the pipe was manually winched out of the stream or lake bed. Once extracted, the samples were labeled and capped as described for the lake samples.

\subsection{Sample Processing}

Two cores were collected at each location to provide sufficient sample volume. Following core retrieval, cores were transported to the sample processing facility, where they were cut open longitudinally using a circular saw. Each core was divided into five segments representing depths of 
0.0-1.0 foot (core segment 1), 1.0-2.0 feet (core segment 2), 2.0-4.0 feet (core segment 3), 4.0-6.0 feet (core segment 4), and 6.0-8.0 feet (core segment 5). In cases where the core was longer than 8 feet, the excess material was discarded. In most cases, the cores were shorter than 8 feet, and therefore, all five intervals were not fully represented.

Subsamples for volatile organic analytes (VOAs) were collected from the cores at approximately half of the sampling locations. When sampling these cores, the VOA samples were collected immediately upon opening the core tube. VOA containers were completely filled, leaving no head space. Following VOA collection, the field geologist examined the core and recorded detailed observations on a geologic log. Then each core segment was individually composited (homogenized) in a stainless-steel bowl. After a segment was adequately homogenized, sample containers were filled in order of volatilization sensitivity. Each container was labeled with the sample identification, date, time, and appropriate analysis. For the 1-foot segments (0.0-1.0-foot and 1.0-2.0-foot), sufficient sample volume was not available. Therefore, a minimum number of containers was filled from these core segments using the prioritization in the Work Plan Assessment (Nichols 1995). All 2-foot segments had ample sample volume.

Filled sample containers were immediately placed on ice in a portable cooler. Upon completion of sample processing for a particular location, the portable cooler was placed inside a walk-in cooler. Chain-of-custody sheets were filled out for each core segment and maintained with the samples. When all the cores had been processed, the samples were shipped to an analytical laboratory. Appropriate quality assurance/quality control procedures were followed at all times during sample collection and processing. Appendix A identifies all sample location codes. Analyses performed at each location are described in Appendix B. Some of the samples were analyzed for organics.

\subsection{Sample Locations}

Sampling locations were identified by Universal Transverse Mercator (UTM) coordinates in Par Pond and Pond C, by longitude and latitude coordinates in L Lake, and by maps for SRS streams and Lake Marion.

For Par Pond and Pond C (Figure 1), the UTM coordinates were plotted on a 7.5-minute topographic quadrangle map. Using the plotted locations on the map, the coring equipment was sited using the

map and visual cues (landmarks, topographic features, etc.). Once in position, a Magellan ${ }^{\circledR}$, Model 1500 Global Positioning System (GPS) was used to obtain exact position data in the form of longitude and latitude corrected to the 1927 North American datum corresponding to the 7.5-minute quadrangles. The coordinates for each location are presented in Table 1. As a check, map locations were converted from UTM to longitude and latitude and compared to the GPS readout for each location.

For L Lake (Figure 1), map locations and longitude and latitude coordinates were determined using the SRS digitized map. The coring equipment on L Lake was positioned in the same manner as at Par Pond (map/visual), and the GPS was used to determine exact location coordinates. 


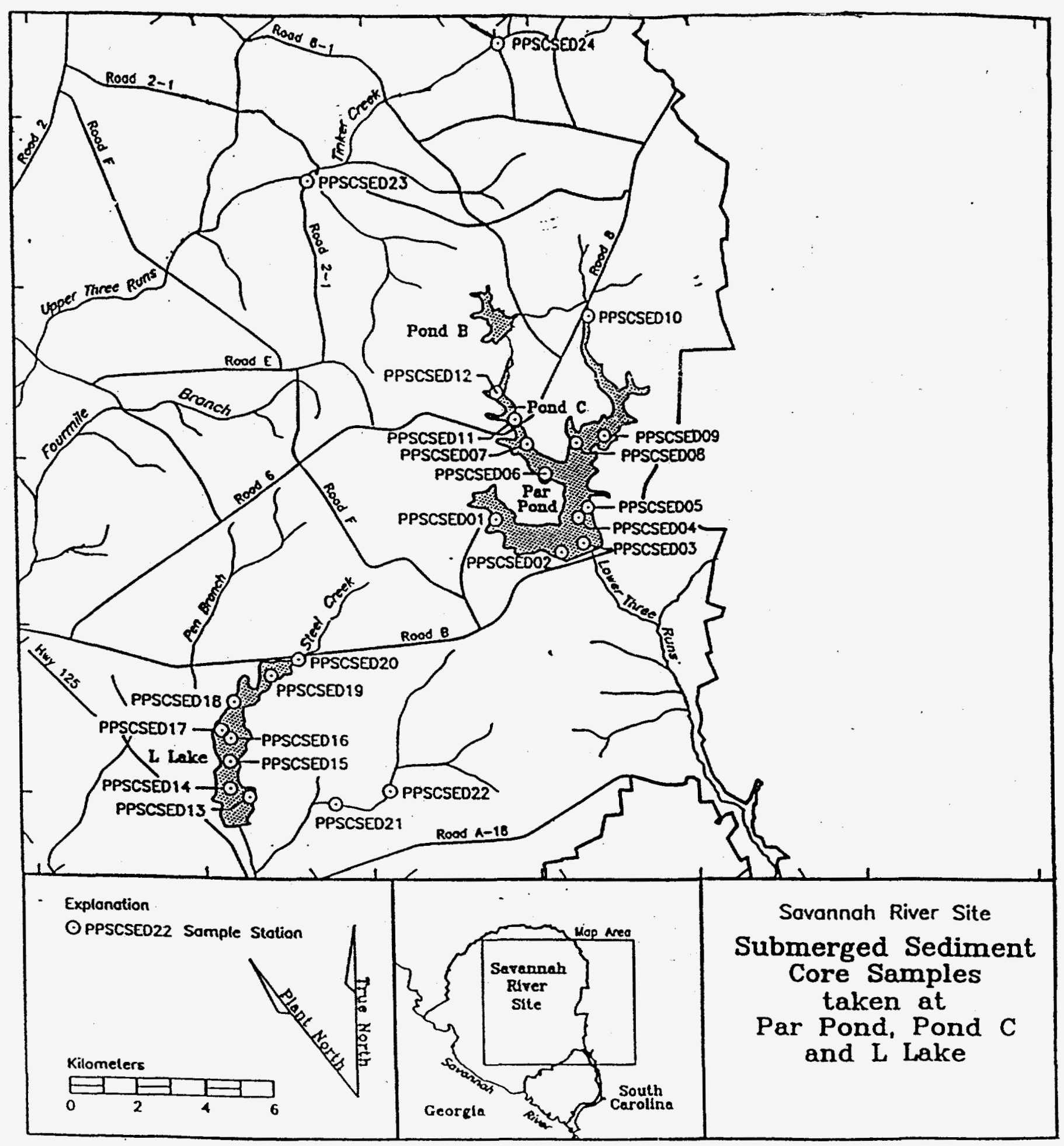

Figure 1. Sample locations for SRS sediment cores. 
Table 1. Universal Transverse Mercator coordinates for all sediment core locations in Par Pond, Pond C, L Lake, Meyer's Branch, Mill Creek, Tinker Creek, and Lake Marion. 1995.

\begin{tabular}{|c|c|c|c|c|c|}
\hline \multirow{3}{*}{ Location } & \multirow{3}{*}{ Sample ID } & \multicolumn{2}{|c|}{ Proposed location } & \multicolumn{2}{|c|}{ Actual location } \\
\hline & & \multirow{2}{*}{ Longitude } & \multirow{3}{*}{$\begin{array}{l}\text { Latitude } \\
33-14-37 \mathrm{~N}\end{array}$} & \multirow[b]{2}{*}{ Longitude } & \multirow[b]{2}{*}{ Latitude } \\
\hline & & & & & \\
\hline \multirow[t]{10}{*}{ Par Pond } & PPSC-SED01 & $81-32-53 W$ & & $81-32-59 W$ & $33-14-38 N$ \\
\hline & PPSC-SED02 & $81-31-30 W$ & $33-14-04 N$ & $81-31-41 W$ & $33-14-07 N$ \\
\hline & PPSC-SED03 & $81-31-11 W$ & $33-14-15 N$ & $81-31-14 W$ & $33-14-16 N$ \\
\hline & PPSC-SED04 & $81-31-17 \mathrm{~W}$ & $33-14-39 N$ & $81-31-20 W$ & $33-14-41 N$ \\
\hline & PPSC-SED05 & $81-31-05 W$ & $33-14-54 \mathrm{~N}$ & $81-31-08 W$ & $33-14-51 N$ \\
\hline & PPSC-SED06 & $81-32-00 \mathrm{~W}$ & $33-15-30 \mathrm{~N}$ & $81-31-59 W$ & $33-15-23 N$ \\
\hline & PPSC-SED07 & $81-32-20 W$ & $33-15-53 N$ & $81-32-20 W$ & $33-15-51 N$ \\
\hline & PPSC-SED08 & $81-31-25 W$ & $33-15-49 N$ & $81-31-21 W$ & $33-15-53 N$ \\
\hline & PPSC-SED09 & $81-30-50 W$ & $33-16-01 \mathrm{~N}$ & $81-30-46 W$ & $33-16-00 \mathrm{~N}$ \\
\hline & PPSC-SED10 & $81-31-03 W$ & $33-17-55 N$ & $81-31-05 W$ & $33-17-54 N$ \\
\hline \multirow[t]{2}{*}{ Pond C } & PPSC-SED11 & $81-32-36 W$ & $33-16-16 \mathrm{~N}$ & $81-32-34 W$ & $33-16-15 N$ \\
\hline & PPSC-SED12 & $81-32-58 W$ & $33-16-40 \mathrm{~N}$ & $81-32-56 \mathrm{~W}$ & $33-16-40 \mathrm{~N}$ \\
\hline \multirow[t]{8}{*}{ L Lake } & PPSC-SED13 & $81-37-51 W$ & $33-10-04 N$ & $81-37-47 W$ & $33-10-07 \mathrm{~N}$ \\
\hline & PPSC-SED14 & $81-38-12 W$ & $33-10-21 \mathrm{~N}$ & $81-38-09 W$ & $33-10-15 N$ \\
\hline & PPSC-SED15 & $81-38-12 W$ & $33-10-35 N$ & $81-38-09 W$ & $33-10-41 \mathrm{~N}$ \\
\hline & PPSC-SED16 & $81-38-11 W$ & $33-10-59 \mathrm{~N}$ & $81-38-08 W$ & $33-11-04 N$ \\
\hline & PPSC-SED17 & $81-38-11 W$ & $33-11-27 N$ & $81-38-18 W$ & $33-11-11 \mathrm{~N}$ \\
\hline & PPSC-SED18 & $81-38-05 W$ & $33-11-45 \mathrm{~N}$ & $81-38-04 W$ & $33-11-39 N$ \\
\hline & PPSC-SED19 & $81-37-21 W$ & $33-12-02 \mathrm{~N}$ & $81-37-20 W$ & $33-12-05 N$ \\
\hline & PPSC-SED20 & $81-37-00 \mathrm{~W}$ & $33-12-18 N$ & $81-36-47 W$ & $33-12-21 N$ \\
\hline \multirow[t]{2}{*}{ Meyer's Branch } & PPSC-SED21 & $N A^{1}$ & NA & $81-36-07 W$ & $33-10-01 \mathrm{~N}$ \\
\hline & PPSC-SED22 & NA & NA & $81-35-05 W$ & $33-10-14 N$ \\
\hline Mill Creek & PPSC-SED23 & NA & NA & $81-36-31 W$ & $33-20-01 N$ \\
\hline Tinker Creek & PPSC-SED24 & NA & NA & $81-32-51 W$ & $33-22-10 \mathrm{~N}$ \\
\hline Lake Marion & PPSC-SED25 & NA & NA & $80-30-15 W$ & $33-33-11 N$ \\
\hline
\end{tabular}

${ }^{1} \mathrm{NA}=$ not applicable 
The SRS stream locations consisted of two sites on Meyer's Branch, one site on Mill Creek, and one site on Tinker Creek. UTM coordinates for the stream locations were not provided. However, locations were sited based on intersections of the streams with SRS roads. GPS was used to obtain longitude and latitude coordinates and the distance from a landmark (i.e., bridge) to the sampling sites was recorded. A similar method was used to locate the sample site at Lake Marion.

\subsection{Field Results and Observations}

\subsection{Lacustrine/Alluvial Channel Sediment Thickness}

Descriptions of each core are presented in Table 2.

\subsubsection{Par Pond}

At 8 of 10 sampling locations, recently deposited material was completely penetrated with the core

- bottoming out in undisturbed soils. Recently deposited material refers to material deposited in recent geologic time. At six of these eight locations, the undisturbed soil was in the "B" soil horizon described in Looney et al. (1989) and other SRS stratigraphic studies. The cores usually were composed of a clayey sand ranging from a fine grained to a very fine-to-coarse grained sand, with clay contents in ranges of $10-20 \%$ to $30-40 \%$. The unit (a mass of sedimentary material occurring in a distinct layer classified as a unit based on character, property, or attribute) was always mottled; the dominant colors were dark yellowish orange and moderate reddish brown, and less frequently, very pale orange. Some cores were silty, medium to coarse-grained sand; one was a sandy silt.

At two locations, SED-03 and SED-09, apparently undisturbed soils that were distinct from the "B" soil horizon were encountered. These were dark yellowish-orange or light gray clayey sands. At all Par Pond locations where recently deposited sediments were fully penetrated, these sediments ranged from 1.5-4.8 feet thick. Five of these were shallow-water environments (flooded terrestrial sites under less than $6.4 \mathrm{~m}$ [21 feet] of water) and the remaining were former (prior to the construction of the reservoir) or ancestral alluvial channel sites. At two of the channel sites (SED-04 and SED-10), recent sediments were not fully penetrated even though the total lengths of these cores were 5.8 and 10.0 feet.

\subsubsection{Pond C}

Both Pond C sampling locations were in shallow water and undisturbed soils were encountered at both. Thickness of recent sediments ranged from 2.5-3.2 feet.

\subsubsection{Lake}

In L-Lake cores, the "B" soil horizon was encountered in only the single nonchannel, or shallow water location (SED-13). Undisturbed soils were encountered at three other locations, and recent soils were not fully penetrated at the remaining four locations. Recent sediment thickness ranged from 3.6 to more than 10 feet, based on the cores never penetrating the recent material. 
Table 2. Description of sediment cores from Par Pond, Pond C, L Lake, Meyer's Branch, Mill Creek, Tinker Creek, and Lake Marion. 1995.

\begin{tabular}{|c|c|c|c|c|c|c|}
\hline Location & Sample ID & $\begin{array}{l}\text { Location } \\
\text { type }\end{array}$ & $\begin{array}{l}\text { Thickness } \\
\text { of recent } \\
\text { sediment } \\
\text { (feet) }\end{array}$ & $\begin{array}{l}\text { Water } \\
\text { depth } \\
\text { (feet) }\end{array}$ & $\begin{array}{l}\text { Undisturbed } \\
\text { soil marker }\end{array}$ & $\begin{array}{l}\text { Recent } \\
\text { material }\end{array}$ \\
\hline 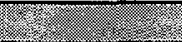 & 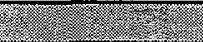 & 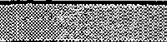 & 62 & 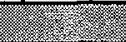 & 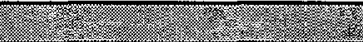 & 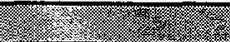 \\
\hline \multirow[t]{10}{*}{ Par Pond } & $\begin{array}{l}\text { PPSC- } \\
\text { SED01 }\end{array}$ & Shallow & 2.0 & 5.5 & Mottled "B" Soil & $\begin{array}{l}\text { Organic soil } \\
\text { over sand }\end{array}$ \\
\hline & $\begin{array}{l}\text { PPSC- } \\
\text { SED02 }\end{array}$ & Shallow & 4.8 & 10 & Mottled "B" Soil & Sand \\
\hline & $\begin{array}{l}\text { PPSC- } \\
\text { SED03 }\end{array}$ & Channel & 4.0 & 41 & Light gray clayey sand & Sand \\
\hline & $\begin{array}{l}\text { PPSC- } \\
\text { SED04 }\end{array}$ & Channel & $\mathrm{UK}^{1}$ & $45^{2}$ & $\mathrm{NA}^{3}$ & Sand \\
\hline & $\begin{array}{l}\text { PPSC- } \\
\text { SED05 }\end{array}$ & Shallow & 3.4 & $15^{2}$ & Mottled "B" Soil & $\begin{array}{l}\text { Sand, } \\
\text { overlying } \\
\text { organic soil }\end{array}$ \\
\hline & $\begin{array}{l}\text { PPSC- } \\
\text { SED06 }\end{array}$ & Channel & 3.2 & 25 & Mottled "B" Soil & $\begin{array}{l}\text { Sand, silty } \\
\text { sand with } \\
\text { roots }\end{array}$ \\
\hline & $\begin{array}{l}\text { PPSC- } \\
\text { SED07 }\end{array}$ & Shallow & 4.0 & 14 & Mottled "B" Soil & $\begin{array}{l}\text { Organic silty } \\
\text { sand over } \\
\text { sand }\end{array}$ \\
\hline & $\begin{array}{l}\text { PPSC- } \\
\text { SED08 }\end{array}$ & Shallow & 1.5 & 21 & Mottled "B" Soil & $\begin{array}{l}\text { Organic } \\
\text { silty/clayey } \\
\text { sand over } \\
\text { silty/clayey } \\
\text { sand }\end{array}$ \\
\hline & $\begin{array}{l}\text { PPSC- } \\
\text { SED09 }\end{array}$ & Channel & 3.0 & 37 & $\begin{array}{l}\text { Dark yellowish-orange } \\
\text { clayey sand over light } \\
\text { gray clayey sand }\end{array}$ & Sand \\
\hline & $\begin{array}{l}\text { PPSC- } \\
\text { SED10 }\end{array}$ & Channel & UK & 9 & NA & $\begin{array}{l}\text { Silty sand } \\
\text { over sand }\end{array}$ \\
\hline \multirow[t]{2}{*}{ Pond $\mathrm{C}$} & $\begin{array}{l}\text { PPSC- } \\
\text { SED11 }\end{array}$ & Shallow & 2.5 & 18 & Mottled "B" Soil & $\begin{array}{l}\text { Organic soil } \\
\text { over sand }\end{array}$ \\
\hline & $\begin{array}{l}\text { PPSC- } \\
\text { SED12 }\end{array}$ & Shallow & 3.2 & 9 & $\begin{array}{l}\text { Dark yellowish-orange } \\
\text { SP-SC } \text { interbedded }^{4} \text { with light gray clay. }\end{array}$ & $\begin{array}{l}\text { Organic soil } \\
\text { over sand }\end{array}$ \\
\hline \multirow[t]{3}{*}{ L Lake } & $\begin{array}{l}\text { PPSC- } \\
\text { SED13 }\end{array}$ & Shallow & 6.3 & 10 & Mottled "B" Soil & Sand \\
\hline & $\begin{array}{l}\text { PPSC- } \\
\text { SED14 }\end{array}$ & Channel & UK & 47 & NA & $\begin{array}{l}\text { Sand over } \\
\text { organic soil }\end{array}$ \\
\hline & $\begin{array}{l}\text { PPSC- } \\
\text { SED15 }\end{array}$ & Channel & 9.9 & 51 & $\begin{array}{l}\text { Dark yellowish-orange } \\
\text { sand with thin clay }\end{array}$ & $\begin{array}{l}\text { Rooted } \\
\text { clayey sand } \\
\text { over organic } \\
\text { rich sand and } \\
\text { organic clay } \\
\text { interbedded }\end{array}$ \\
\hline
\end{tabular}

${ }^{1} \mathrm{UK}=$ unknown; recent sediment was not completely penetrated

${ }^{2}$ Approximate water depths from 7.5-minute topographic maps

${ }^{3} \mathrm{NA}=$ not applicable

${ }^{4} \mathrm{SP}-\mathrm{SC}=$ poorly graded, sand-clayey sand 
WSRC-TR-96-0238

Table 2 (continued). Description of sediment cores from Par Pond, Pond C, L Lake, Meyer's Branch, Mill Creek, Tinker Creek, and Lake Marion. 1995.

\begin{tabular}{|c|c|c|c|c|c|c|}
\hline Location & Sample ID & $\begin{array}{l}\text { Location } \\
\text { type }\end{array}$ & $\begin{array}{l}\text { Thickness } \\
\text { of recent } \\
\text { sediment } \\
\text { (feet) }\end{array}$ & $\begin{array}{l}\text { Water } \\
\text { depth } \\
\text { (feet) }\end{array}$ & $\begin{array}{l}\text { Undisturbed } \\
\text { soil marker }\end{array}$ & $\begin{array}{l}\text { Recent } \\
\text { material }\end{array}$ \\
\hline 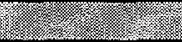 & 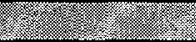 & 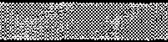 & 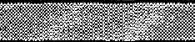 & $2=$ & 20.0 & 20 \\
\hline \multirow[t]{5}{*}{ L Lake } & $\begin{array}{l}\text { PPSC- } \\
\text { SED16 }\end{array}$ & Channel & 6.5 & 48 & $\begin{array}{l}\text { Tan clay of Dry Branch } \\
\text { Formation }\end{array}$ & $\begin{array}{l}\text { Organic soil } \\
\text { over sand }\end{array}$ \\
\hline & $\begin{array}{l}\text { PPSC- } \\
\text { SED17 }\end{array}$ & Channel & 3.6 & 32 & $\begin{array}{l}\text { Light gray SC with } \\
20-30 \% \text { clay }\end{array}$ & Sand \\
\hline & $\begin{array}{l}\text { PPSC- } \\
\text { SED18 }\end{array}$ & Channel & UK & 17 & NA & Sand \\
\hline & $\begin{array}{l}\text { PPSC- } \\
\text { SED19 }\end{array}$ & Channel & UK & 22 & NA & $\begin{array}{l}\text { Clayey sand } \\
\text { organic, over } \\
\text { sand }\end{array}$ \\
\hline & $\begin{array}{l}\text { PPSC- } \\
\text { SED20 }\end{array}$ & Channel & UK & $10^{2}$ & NA & $\begin{array}{l}\text { Organic rich } \\
\text { SC over sand } \\
\text { with pebbles }\end{array}$ \\
\hline \multirow[t]{2}{*}{$\begin{array}{l}\text { Meyer's } \\
\text { Branch }\end{array}$} & $\begin{array}{l}\text { PPSC- } \\
\text { SED21 }\end{array}$ & Stream & UK & $<1$ & NA & $\begin{array}{l}\text { Sand over } \\
\text { organic rich } \\
\text { clay }\end{array}$ \\
\hline & $\begin{array}{l}\text { PPSC- } \\
\text { SED22 }\end{array}$ & Stream & 3.9 & $<1$ & $\begin{array}{l}\text { McBean yellowish-gray } \\
\text { sand }\end{array}$ & $\begin{array}{l}\text { Sand over } \\
\text { sand with } \\
\text { clay }\end{array}$ \\
\hline Mill Creek & $\begin{array}{l}\text { PPSC- } \\
\text { SED23 }\end{array}$ & Stream & 6.8 & $<1$ & Green clay & $\begin{array}{l}\text { Sand over } \\
\text { organic soil } \\
\text { over sand } \\
\text { and SC } \\
\end{array}$ \\
\hline $\begin{array}{l}\text { Tinker } \\
\text { Creek }\end{array}$ & $\begin{array}{l}\text { PPSC- } \\
\text { SED24 }\end{array}$ & Stream & 4.1 & $<1$ & Green clay & $\begin{array}{l}\text { Sand and } \\
\text { gravel }\end{array}$ \\
\hline $\begin{array}{l}\text { Lake } \\
\text { Marion }\end{array}$ & $\begin{array}{l}\text { PPSC- } \\
\text { SED25 }\end{array}$ & $\begin{array}{l}\text { Shallow } \\
\text { Lake }\end{array}$ & UK & $<1$ & NA & Sand \\
\hline
\end{tabular}

${ }^{1} \mathrm{UK}=$ unknown; recent sediment was not completely penetrated

${ }^{2}$ Approximate water depths from 7.5-minute topographic maps

${ }^{3} \mathrm{NA}=$ not applicable

${ }^{4} \mathrm{SP}-\mathrm{SC}=$ poorly graded, sand-clayey sand 


\subsubsection{Streams and Lake Marion}

Stream sediments were fully penetrated at three of four locations with thickness of the sediments ranging from 3.9-6.8 feet. The total length of the core at the one remaining stream site was within the same range. At Lake Marion, the core was 5.7 feet long, but it is not clear whether undisturbed samples were encountered.

\section{$5.2 \quad$ Lithology Of Recent Sediments}

Recently deposited sediments encountered at Par Pond, Pond C, L Lake, and local streams included organic-rich, anoxic material representing very recent deposition or bioactivity; coarse grained sands representing channel fill and perhaps recent storm deposition; and silty and clayey sands, possibly indicative of less recent, buried lake bottom. Five distinct lithologic units were identified among the 25 sampling locations. Descriptions of the recent sediments at the sampling locations are provided in Table 2. No stratigraphic correlation was attempted, nor is any inferred; however, observed lithologic similarities may provide evidence of depositional processes and prove useful when attempting to correlate contaminant concentrations in the sediments. The five lithologic units are described in the following paragraphs.

\subsubsection{Lithology 1}

This lithology was found most frequently at Par Pond and Pond C, usually as the uppermost layer. It is associated with the shallower locations where bottom vegetation is present and active decay processes are evident. It was described as a very fine to fine grained silty sand or organic soil, from pale to dusky yellowish-brown, or more commonly, brownish- to greenish-black or dark gray. It was typically soft and saturated, and contained abundant organic material including roots and decaying twigs and leaves, with an earthy or sulfurous odor. In one location, small bivalve shells were present in the unit.

Lithology 1 was not common at L Lake, where most of the sampling locations were in deep water. At one stream location, this lithology was a buried layer, possibly representing a former levee or stream bank.

\subsubsection{Lithology 2}

Lithology 2 was similar to Lithology 1 but was lighter in color, contained less distinguishable organic matter, and was typically a buried horizon. It was observed at four locations in Par Pond, two locations in L Lake, and at Mill Creek. The lithology was described as silty or clayey sand, from very fine to coarse grained, and with silt or clay content from $10-30 \%$. The color was typically pale to moderate yellowish-brown or light brownish-gray. The layer's texture was soft and fluffy, with a distinct lack of density. It may represent a stage of organic decay later than that of Lithology 1.

\subsubsection{Lithology 3}

This lithology was present at all but one Par Pond location, at one Pond C location, and at all L Lake and background locations. It included medium-to-coarse, and coarse grained, loose sands typical of alluvial channel fill, or colluvium or storm deposits in the shallower locations. The unit was described as a poorly graded sand, mostly medium-to-coarse grained and sometimes coarse grained (the stream sediments were coarser than the lake sediments). The color ranged from very pale orange to dark yellowish-orange, from pale to dark yellowish- brown, from light brown to light 
brownish-gray, and from light gray to grayish-orange. It rarely occurred as olive-black or brownishblack.

\subsubsection{Lithology 4}

Lithology 4 was also a sand unit but was finer grained than Lithology 3 and, consequently, firmer and more cohesive. It was described as a fine-to-medium or medium sand, pale to moderate to dark yellowish-brown, yellowish-gray, grayish-orange, brownish-gray, or medium light gray. This lithology was observed at three Par Pond, one Pond C, two L-Lake, and two stream locations. The unit was always buried, but never deeper than 1-2 feet.

\subsubsection{Lithology 5}

This lithology is distinct from Lithologies 3 and 4 only in that it includes a small-to-moderate percentage of matrix clay. The winit was observed at three Par Pond, one Pond $C$, and two background locations, including Lake Marion. It was not evident at L Lake. It was typically a thin unit (less than 2 feet thick) and was immediately below apparent recent sediments. It may represent an older soil horizon that has been softened by its submergence, however, it was not observed consistently above the " $\mathrm{B}$ " soil horizon. The unit was described as a clayey sand, usually fine-tomedium grained, with 5-20\% clay. Colors observed in the unit included light brown, light gray, yellowish-gray, dark yellowish-orange, pale yellowish-brown, and light greenish-gray. 


\subsection{Analytical Results}

\section{I Nonradiological Constituents Analvsis}

\subsubsection{Data Analysis}

The results from the nonradiological constituents were screened against the threshold values from the most recent EPA Region IV standards for potential contaminants of concern (PCOC) using the following protocol. The PCOCs and their screening values are presented in Table 3 . Results were not statistically compared because only one analyte was detected above the screening value. Before the data were screened they were reviewed and treated as follows:

1. All data from laboratory blanks, trip blanks, field blanks, and rinsate blanks were removed from the results data file. These data were archived in a quality assurance file. All matrix spike results were removed from the data file.

2. All data qualified with an " $R$ " were removed from the results data file.

3. All data qualified with a " $U$ " were reported at one-half the detection limit (termed a modified result).

4. If a sample location was determined to have $100 \%$ nondetects of a given analyte, this analyte was eliminated from consideration as a PCOC for this location.

5. For each analyte and core segment, all modified results were averaged to get a sample mean value. The number of records used to produce the sample mean was recorded in another field.

6. For each analyte and core segment, results of duplicate and split samples were dropped and the parent result was used.

7. In all other cases, the results were not modified.

8. The analyte and core segment data were compared to the EPA sediment screening values and to each other.

\subsubsection{Comparison of Results with EPA Region IV Screening Criteria}

Tables 4, 5, and 6 summarize the results of screening the contaminants in Par Pond (including Pond C), L Lake, and the pooled background locations against EPA Region IV PCOC values.

Of all the organics and metals screened, only arsenic and mercury were detected. Most of these results were qualified as nondetected (u), and, to be conservative, reported at one-half the detection limit. Their reported concentrations sometimes exceeded screening values. Three results were detected, but estimated quantities were not used to identify PCOCs. Only one result, for mercury, was unqualified. Mercury was detected in one core segment in L Lake (Table 5).

Based on this analysis, no metals or organics were identified as PCOC in Par Pond, L Lake, or the background locations. A complete list of the analytical results is presented in the Quality Control Summary Report (WSRC 1995). 
Table 3. EPA Region IV screening values for potential contaminants of concern. (EPA 1995).

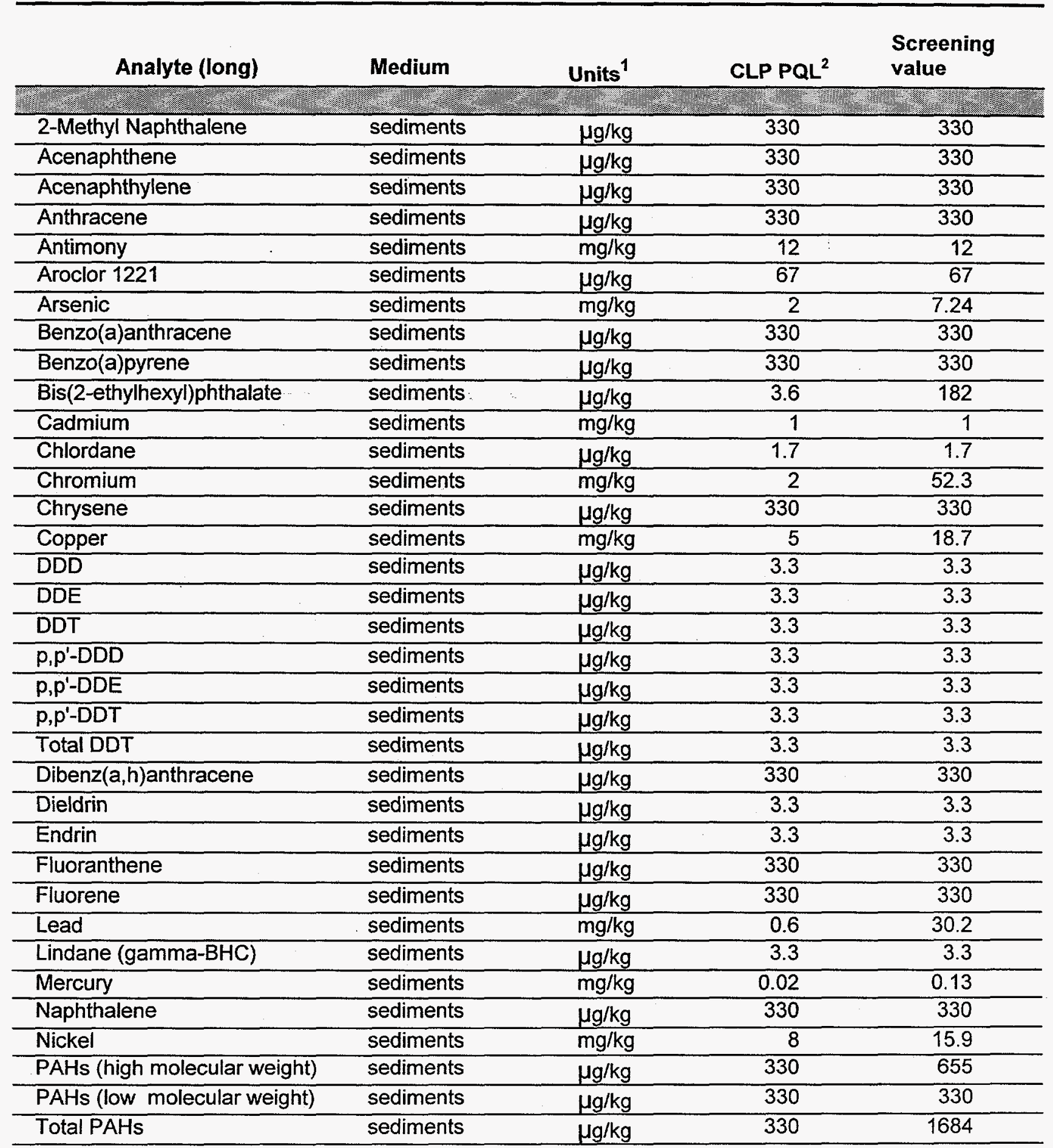

$1 \mu \mathrm{g} / \mathrm{kg}=$ microgram per kilogram or parts per billion; $\mathrm{mg} / \mathrm{kg}=$ milligram per kilogram or parts per million.

2 CLP PQL $=$ Contract Laboratory Program Practical Quantitation Limit. 
Table 3 (continued). EPA Region IV screening values for potential contaminants of concern. (EPA 1995).

\begin{tabular}{lllrc}
\hline Analyte (long) & Medium & Units & & \multicolumn{2}{c}{$\begin{array}{l}\text { Screening } \\
\text { value }\end{array}$} \\
\hline & & & CLP PQL $^{2}$ & \\
\hline Phenanthrene & sediments & $\mu \mathrm{g} / \mathrm{kg}$ & 330 & 330 \\
\hline Pyrene & sediments & $\mu \mathrm{g} / \mathrm{kg}$ & 330 & 330 \\
\hline Silver & sediments & $\mathrm{mg} / \mathrm{kg}$ & 2 & 2 \\
\hline Total PCBs & sediments & $\mu \mathrm{gg} / \mathrm{kg}$ & 33 & 33 \\
\hline Zinc & sediments & $\mathrm{mg} / \mathrm{kg}$ & 4 & 124 \\
\hline
\end{tabular}

$1 \mu \mathrm{g} / \mathrm{kg}=$ microgram per kilogram or parts per billion; $\mathrm{mg} / \mathrm{kg}=$ milligram per kilogram or parts per million.

2 CLP PQL = Contract Laboratory Program Practical Quantitation Limit.

\subsection{Radiological Constituents}

\subsubsection{Data Analysis}

EPA has not developed screening criteria for radiological constituents; therefore, no screening comparisons were done with the radiological results.

Results were statistically compared by pooling the background locations and comparing a single background value to Par Pond and to L Lake. Before the data were analyzed they were reviewed and treated as follows:

1. All data from laboratory blanks, trip blanks, field blanks, and rinsate blanks were removed from the results data file. These data were archived in a quality assurance file. All matrix spike results were removed from the data file.

2. All data qualified with an " $R$ " were removed from the results data file.

3. All data qualified with a "U" were reported at one-half the detection limit (termed a modified result).

4. For each analyte and core segment, all modified results were averaged to get a sample mean value. The number of records used to produce the sample mean was recorded in another field.

5. For each analyte and core segment, results of duplicate and linked original samples results were averaged to get a mean value. The number of records used to calculate each value was recorded.

6. In all other cases, the results were not modified.

7. The analyte data were statistically compared with each other.

General descriptive statistics including the mean, degrees of freedom, standard error, and range were derived using SPSS Release 6.1. Tests of normality included the Lilliefors and Shapiro-Wilks tests. Differences in locations were evaluated using the Kruskal-Wallis one-way nonparametric analysis of variance. 
Table 4. Results of a comparison of nonradiological contaminants in Par Pond core segments with EPA Region IV potential contaminants of concern screening values.

\begin{tabular}{|c|c|c|c|c|c|}
\hline Analyte & $\begin{array}{l}\text { Sample } \\
\text { location }^{1}\end{array}$ & $\begin{array}{l}\text { Detection limit } \\
\text { (mg/kg) }\end{array}$ & $\begin{array}{l}\text { Analytical } \\
\text { result } \\
\text { (mg/kg) }\end{array}$ & $\begin{array}{l}\text { Result } \\
\text { qualifier } \\
\text { code }^{2}\end{array}$ & $\begin{array}{l}\text { EPA Region IV } \\
\text { Screening Value } \\
\text { (mg/kg) }\end{array}$ \\
\hline \multicolumn{6}{|c|}{ 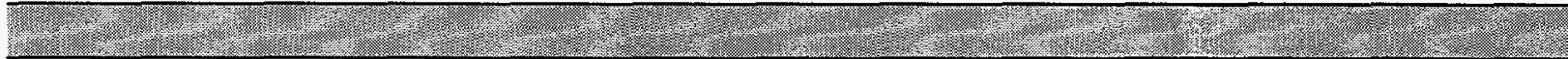 } \\
\hline Arsenic & PPSC 0102 & 15.3 & 7.67 & $\mathrm{~J}$ & 7.24 \\
\hline Arsenic & PPSC 0604 & 13.4 & 7.43 & J & 7.24 \\
\hline Arsenic & PPSC 0704 & 16.2 & 7.31 & $J$ & 7.24 \\
\hline Arsenic & PPSC 0103 & 15.4 & 7.7 & $\bar{U}$ & 7.24 \\
\hline Arsenic & PPSC 0201 & 16.6 & 8.3 & $\bar{U}$ & 7.24 \\
\hline Arsenic & PPSC 0202 & 17.2 & 8.6 & $\bar{U}$ & 7.24 \\
\hline Arsenic & PPSC 0203 & 15.6 & 7.8 & $\bar{U}$ & 7.24 \\
\hline Arsenic & $\overline{\text { PPSC } 0204}$ & 15.5 & 7.75 & $\bar{U}$ & 7.24 \\
\hline Arsenic & PPSC 0205 & 15.9 & 7.95 & $\bar{U}$ & 7.24 \\
\hline Arsenic & PPSC 0301 & 17.5 & 8.75 & $\bar{U}$ & 7.24 \\
\hline Arsenic & PPSC 0302 & 16.1 & 8.05 & $\bar{U}$ & 7.24 \\
\hline Arsenic & PPSC 0303 & 15.9 & 7.95 & $U$ & 7.24 \\
\hline Arsenic & PPSC 0304 & 16.9 & 8.45 & $\bar{U}$ & 7.24 \\
\hline Arsenic & PPSC 0401 & 16.3 & 8.15 & $\bar{U}$ & 7.24 \\
\hline Arsenic & PPSC 0402 & 16.5 & 8.25 & $\bar{U}$ & 7.24 \\
\hline Arsenic & PPSC 0403 & 16.1 & 8.05 & $\mathrm{U}$ & 7.24 \\
\hline Arsenic & PPSC 0404 & 16.5 & 8.25 & $\bar{U}$ & 7.24 \\
\hline Arsenic & PPSC 0501 & 17.8 & 8.9 & U & 7.24 \\
\hline Arsenic & PPSC 0701 & 17.1 & 8.55 & $\bar{U}$ & 7.24 \\
\hline Arsenic & $\overline{P P S C} 0702$ & 17.0 & 8.5 & $\bar{U}$ & 7.24 \\
\hline Arsenic & PPSC 0703 & 16.3 & 8.15 & $\mathrm{U}$ & 7.24 \\
\hline Arsenic & PPSC 0801 & 20.1 & 10.05 & $U$ & 7.24 \\
\hline Arsenic & PPSC 0802 & 18.2 & 9.1 & $\bar{U}$ & 7.24 \\
\hline Arsenic & PPSC 0901 & 16.9 & 8.45 & $\bar{U}$ & 7.24 \\
\hline Arsenic & PPSC 0902 & 16.9 & 8.45 & U & 7.24 \\
\hline Arsenic & PPSC 0903 & 17.3 & 8.65 & $\mathrm{U}$ & 7.24 \\
\hline Arsenic & PPSC 1001 & 36.2 & 18.1 & $\bar{U}$ & 7.24 \\
\hline Arsenic & PPSC 1002 & 25.6 & 12.8 & $\bar{U}$ & 7.24 \\
\hline Arsenic & PPSC 1003 & 23.6 & 11.8 & 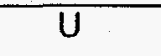 & 7.24 \\
\hline Arsenic & PPSC 1004 & 29.7 & 14.85 & $\bar{U}$ & 7.24 \\
\hline Arsenic & PPSC 1005 & 20.7 & 10.35 & $\bar{U}$ & 7.24 \\
\hline
\end{tabular}

1 The first two digits identify the sample location; the second two digits identify the core segment.

$2 \mathrm{U}=$ a nondetect; $\mathrm{J}=$ an estimated quantity. 
WSRC-TR-96-0238

Table 5. Results of a comparison of nonradiological contaminants in L-Lake core segments with EPA Region IV potential contaminants of concern screening values.

\begin{tabular}{|c|c|c|c|c|c|}
\hline Analyte & $\begin{array}{l}\text { Sample } \\
\text { location }{ }^{1}\end{array}$ & $\begin{array}{l}\text { Detection limit } \\
\text { (mg/kg) }\end{array}$ & $\begin{array}{l}\text { Analytical } \\
\text { result } \\
(\mathbf{m g} / \mathrm{kg})\end{array}$ & $\begin{array}{l}\text { Result } \\
\text { qualifier } \\
\text { code }^{2}\end{array}$ & $\begin{array}{l}\text { EPA Region IV } \\
\text { Screening Value } \\
\text { (mg/kg) }\end{array}$ \\
\hline 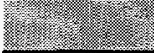 & 20 & (2) & & 8 & 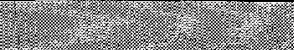 \\
\hline Arsenic & PPSC 1301 & 17.1 & 8.55 & $\mathrm{U}$ & 7.24 \\
\hline Arsenic & PPSC 1302 & 16.8 & 8.40 & $\mathrm{U}$ & 7.24 \\
\hline Arsenic & PPSC 1303 & 17.2 & 8.60 & $\mathrm{U}$ & 7.24 \\
\hline Arsenic & PPSC 1304 & 16.5 & 8.25 & $\mathrm{U}$ & 7.24 \\
\hline Arsenic & PPSC 1401 & 15.1 & 7.55 & $\bar{U}$ & 7.24 \\
\hline Arsenic & PPSC 1402 & 16.9 & 8.45 & $\mathrm{U}$ & 7.24 \\
\hline Arsenic & PPSC 1403 & 17.0 & 8.50 & $\bar{U}$ & 7.24 \\
\hline Arsenic & PPSC 1501 & 27.0 & 13.50 & $\mathrm{U}$ & 7.24 \\
\hline Arsenic & PPSC 1502 & 21.4 & 10.70 & $\mathrm{U}$ & 7.24 \\
\hline Arsenic & PPSC 1503 & 23.6 & 11.80 & $\bar{U}$ & 7.24 \\
\hline Arsenic & PPSC 1504 & 20.4 & 10.20 & $\bar{U}$ & 7.24 \\
\hline Arsenic & PPSC 1505 & 19.7 & 9.85 & $\mathrm{U}$ & 7.24 \\
\hline Arsenic & PPSC 1601 & 21.5 & 10.75 & $\bar{U}$ & 7.24 \\
\hline Arsenic & PPSC 1602 & 20.7 & 10.35 & $\mathrm{U}$ & 7.24 \\
\hline Arsenic & PPSC 1603 & 17.3 & 8.65 & $\mathrm{U}$ & 7.24 \\
\hline Arsenic & PPSC 1604 & 18.0 & 9.00 & $\mathrm{U}$ & 7.24 \\
\hline Arsenic & PPSC 1605 & 18.9 & 9.45 & $\bar{U}$ & 7.24 \\
\hline Arsenic & PPSC 1701 & 16.4 & 8.20 & $\mathrm{U}$ & 7.24 \\
\hline Arsenic & PPSC 1702 & 16.2 & 8.10 & $\mathrm{U}$ & 7.24 \\
\hline Arsenic & PPSC 1703 & 16.2 & 8.10 & $\mathrm{U}$ & 7.24 \\
\hline Arsenic & PPSC 1704 & 16.5 & 8.25 & $\mathrm{U}$ & 7.24 \\
\hline Arsenic & PPSC 1801 & 16.7 & 8.35 & $\bar{U}$ & 7.24 \\
\hline Arsenic & PPSC 1802 & 16.2 & 8.10 & $\mathrm{U}$ & 7.24 \\
\hline Arsenic & PPSC 1803 & 16.4 & 8.20 & $\bar{U}$ & 7.24 \\
\hline Arsenic & PPSC 1902 & 16.5 & 8.25 & $U$ & 7.24 \\
\hline Arsenic & PPSC 1903 & 18.2 & 9.10 & $\mathrm{U}$ & 7.24 \\
\hline Arsenic & PPSC 1904 & 17.6 & 8.80 & $\mathrm{U}$ & 7.24 \\
\hline Arsenic & PPSC 1905 & 18.8 & 9.40 & $U$ & 7.24 \\
\hline Arsenic & PPSC 2001 & 25.0 & 12.50 & $\mathrm{U}$ & 7.24 \\
\hline Arsenic & PPSC 2002 & 18.0 & 9.00 & $\mathrm{U}$ & 7.24 \\
\hline Arsenic & PPSC 2003 & 17.1 & 8.55 & $\bar{U}$ & 7.24 \\
\hline Mercury & PPSC 1702 & 0.0 & 1.21 & & 0.13 \\
\hline
\end{tabular}

1 The first two digits identify the sample location; the second two digits identify the core segment.

$2 \mathrm{U}=$ a nondetect. 
Table 6. Results of a comparison of nonradiological contaminants in background location core segments with EPA Region IV potential contaminants of concern screening values.

\begin{tabular}{|c|c|c|c|c|c|c|}
\hline Location & Analyte & $\begin{array}{l}\text { Sample } \\
\text { location }^{1}\end{array}$ & $\begin{array}{l}\text { Detection } \\
\text { limit } \\
\text { (mg/kg) }\end{array}$ & $\begin{array}{l}\text { Analytical } \\
\text { result } \\
(\mathbf{m g} / \mathrm{kg})\end{array}$ & $\begin{array}{l}\text { Result } \\
\text { qualifier } \\
\text { code }^{2}\end{array}$ & $\begin{array}{l}\text { EPA Region IV } \\
\text { Screening Value } \\
\text { (mg/kg) }\end{array}$ \\
\hline & & & 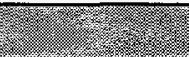 & 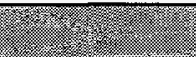 & $\sqrt{20}$ & 2. \\
\hline Mill Creek & Arsenic & PPSC 2301 & 31.4 & 15.7 & $\mathrm{U}$ & 7.24 \\
\hline Mill Creek & Arsenic & PPSC 2302 & 20.0 & 10 & $\bar{U}$ & 7.24 \\
\hline Mill Creek & Arsenic & PPSC 2303 & 19.4 & 9.7 & $\bar{U}$ & 7.24 \\
\hline Mill Creek & Arsenic & PPSC 2304 & 18.2 & 9.1 & $\bar{U}$ & 7.24 \\
\hline Tinker Creek & Arsenic & PPSC 2401 & 18.3 & 9.15 & $\bar{U}$ & 7.24 \\
\hline Tinker Creek & Arsenic & PPSC 2402 & 17.0 & 8.5 & $\bar{U}$ & 7.24 \\
\hline Tinker Creek & Arsenic & PPSC 2403 & 16.3 & -8.15 & 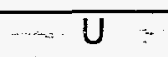 & 7.24 \\
\hline
\end{tabular}

1 The first two digits identify the sample location; the second two digits identify the core segment.

$2 \mathrm{U}=$ a nondetect.

\subsubsection{Comparison of Isotopes in Par Pond and L Lake with Background Locations}

A complete list of the analytical results is presented in the Quality Control Summary Report (WSRC 1995).

Many of the analytical results are reported as negative numbers due to the instrument sensitivity and the potential error in the datum point. Negative values were not truncated to 0.0 to keep the statistical analysis results from being biased high. All background results were pooled, and an average background concentration was used for the comparisons.

\subsubsection{Par Pond}

Par Pond samples had significantly greater concentrations of cesium-137, promethium-146, plutonium-238, and zirconium-95 than the background locations (Table 7).

\subsubsection{L Lake}

L-Lake samples had significantly greater concentrations of cobalt-60, cesium-137, plutonium-238, plutonium-239/240, and strontium-90 than the background locations (Table 8).

\subsubsection{Comparison of Specific Isotope Activity}

General descriptive statistics, including tests of normality, were performed on all the radioisotopes detected at least once during sample analysis (Tables 9-15). All locations and core segments were included in this analysis. 
Table 7. Results of Kruskall-Wallis nonparametric test of concentrations of radioisotopes in Par Pond compared to all background locations.

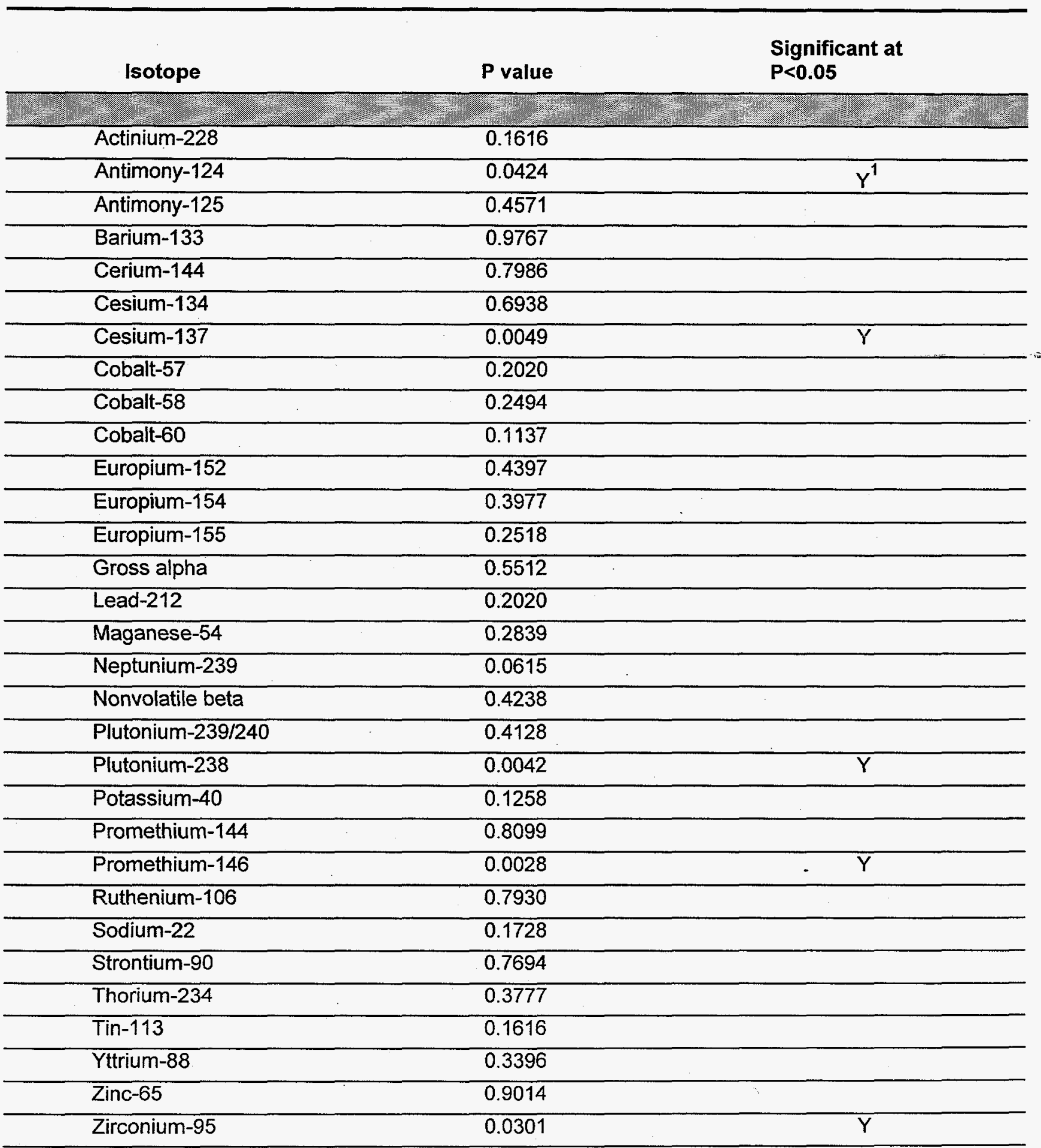

1 This was not considered significant because the mean was a negative value and, therefore, considered a background concentration. 
Table 8. Results of Kruskall-Wallis nonparametric test of concentrations of radioisotopes in L Lake compared to all background locations.

\begin{tabular}{|c|c|c|c|}
\hline Isotope & P value & $\begin{array}{l}\text { Significant at } \\
P<0.05\end{array}$ & \\
\hline \multicolumn{4}{|c|}{ PIT) } \\
\hline Actinium-228 & 0.7552 & & \\
\hline Antimony-124 & 0.5793 & & \\
\hline Antimony-125 & 0.3770 & : & \\
\hline Barium-133 & 0.3770 & & \\
\hline Cerium-144 & 0.9862 & & \\
\hline Cesium-134 & 0.8898 & & \\
\hline$\because \quad$ Cesium -137 & 0.0000 & $Y$ & 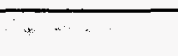 \\
\hline Cobalt-57 & 0.2565 & & \\
\hline Cobalt-58 & 0.6649 & & \\
\hline Cobalt-60 & 0.0006 & $\mathrm{Y}$ & \\
\hline Europium-152 & 0.9724 & & \\
\hline Europium-154 & 0.8693 & & \\
\hline Europium-155 & 0.5201 & & \\
\hline Gross alpha & 0.8931 & & \\
\hline Lead-212 & 0.6776 & & \\
\hline Maganese-54 & 0.8151 & & \\
\hline Neptunium-239 & 0.0683 & & \\
\hline Nonvolatile beta & 0.8159 & & \\
\hline Plutonium-239/240 & 0.0002 & $\bar{Y}$ & \\
\hline Plutonium-238 & 0.0018 & $\bar{Y}$ & \\
\hline Potassium-40 & 0.5215 & & \\
\hline Promethium-144 & 0.4563 & & \\
\hline Promethium-146 & 0.2589 & & \\
\hline Ruthenium-106 & 0.0802 & & \\
\hline Sodium-22 & 0.3631 & & \\
\hline Strontium-90 & 0.0222 & $\bar{Y}$ & \\
\hline Thorium-234 & 0.5443 & & \\
\hline Tin-113 & 0.02271 & $Y^{1}$ & \\
\hline Yttrium-88 & 0.6649 & & \\
\hline Zinc-65 & 0.4407 & & \\
\hline Zirconium-95 & 0.7460 & & \\
\hline
\end{tabular}

1 This was not considered significant because the mean was a negative value and, therefore, considered a background concentration. 
Table 9. General descriptive statistics for radioactive constituents ( $\mathrm{pCi} / \mathrm{g}$ ) in Par Pond sediment cores.

\begin{tabular}{|c|c|c|c|c|c|c|}
\hline Isotope & $\mathbf{N}$ & Mean & Median & $\begin{array}{l}\text { Standard } \\
\text { error }\end{array}$ & Minimum & Maximum \\
\hline 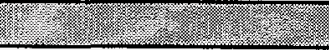 & 5 & 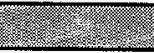 & 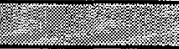 & 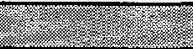 & 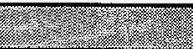 & 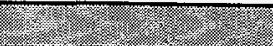 \\
\hline Actinium-228 & 42 & 1.2048 & 1.145 & 0.0635 & 0.514 & 2.21 \\
\hline Antimony-124 & 42 & -0.0014 & -0.0015 & 0.0007 & -0.0129 & 0.0102 \\
\hline Antimony-125 & 42 & 0.0037 & 0.0056 & 0.0021 & -0.045 & 0.041 \\
\hline Barium-133 & 42 & -0.0075 & -0.0002 & 0.0062 & -0.217 & 0.09 \\
\hline Cerium-144 & 42 & -0.0101 & -0.0144 & 0.0049 & -0.095 & 0.0826 \\
\hline Cesium-134 & 42 & -0.008 & -0.0003 & 0.0036 & -0.101 & 0.01 \\
\hline Cesium-137 & 42 & 0.9841 & 0.0292 & 0.3619 & -0.0207 & 11.5 \\
\hline Cobalt-57 & 42 & 0.0006 & 0.0005 & 0.0005 & 0.005 & 0.0096 \\
\hline Cobalt -58 & 42 & -0.0025 & -0.0024 & 0.0006 & -0.0118 & 0.005 \\
\hline Cobalt-60 & 42 & 0.006 & 0.0006 & 0.0024 & -0.0058 & 0.0741 \\
\hline Europium-152 & 42 & 0.0047 & -0.0068 & 0.0099 & -0.0265 & 0.4 \\
\hline Europium-154 & 42 & -0.0099 & -0.0087 & 0.0043 & -0.0679 & 0.0558 \\
\hline Europium-155 & 42 & 0.0192 & 0 & 0.0091 & 0 & 0.33 \\
\hline Gross alpha & 42 & 19.4563 & 18.25 & 1.2079 & 6.15 & 41.25 \\
\hline Lead-212 & 42 & 1.2487 & 1.215 & 0.0645 & 0.5275 & 2.34 \\
\hline Manganese-54 & 42 & 0.0204 & 0.0217 & 0.0015 & -0.005 & 0.0383 \\
\hline Neptunium-239 & 42 & 0.0715 & 0.0054 & 0.0528 & -0.0567 & 2.2 \\
\hline Nonvolatile beta & 40 & 10.1132 & 9.575 & 0.6434 & 2.95 & 21.7 \\
\hline Plutonium-238 & 44 & 0.0202 & 0.0063 & 0.0091 & -0.0043 & 0.39 \\
\hline Plutonium-239/240 & 44 & 0.0104 & 0.0008 & 0.0042 & -0.005 & 0.119 \\
\hline Potassium-40 & 42 & 0.8467 & 0.7765 & 0.0631 & 0.165 & 1.77 \\
\hline Promethium-144 & 42 & 0.0009 & -0.0002 & 0.0006 & -0.0048 & 0.015 \\
\hline Promethium-146 & 42 & 0.0067 & 0.0061 & 0.001 & -0.005 & 0.0307 \\
\hline Ruthenium-106 & 42 & 0.0001 & -0.0015 & 0.005 & -0.0705 & 0.0864 \\
\hline Sodium-22 & 42 & 0.0002 & 0.0006 & 0.0006 & -0.01 & 0.0132 \\
\hline Strontium-90 & 43 & 0.1759 & 0.0319 & 0.0676 & -0.274 & 1.52 \\
\hline Thorium-234 & 42 & 1.3172 & 1.125 & 0.1042 & 0.495 & 3.9 \\
\hline Tin-113 & 42 & -0.0011 & -0.0033 & 0.002 & -0.0187 & 0.07 \\
\hline Yțtrium-88 & 42 & 0.0034 & 0.0029 & 0.0006 & -0.0044 & 0.015 \\
\hline Zinc-65 & 42 & -0.0013 & 0.0015 & 0.002 & -0.0446 & 0.0215 \\
\hline Zirconium-95 & 42 & 0.0146 & 0.0092 & 0.0029 & -0.015 & 0.0698 \\
\hline
\end{tabular}


Table 10. General descriptive statistics for radioactive constituents $(\mathrm{pCi} / \mathrm{g})$ in Pond $\mathrm{C}$ sediment cores.

\begin{tabular}{|c|c|c|c|c|c|c|}
\hline Isotope & $\mathbf{N}$ & Mean & Median & $\begin{array}{l}\text { Standard } \\
\text { error }\end{array}$ & Minimum & Maximum \\
\hline & & & 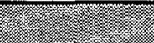 & 70 & 20 & 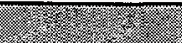 \\
\hline Actinium-228 & 7 & 1.4293 & 1.56 & 0.213 & 0.741 & 2.07 \\
\hline Antimony-124 & 7 & -0.0009 & 0.0033 & 0.0031 & -0.016 & 0.01 \\
\hline Antimony-125 & 7 & 0.0079 & -0.0055 & 0.0179 & -0.005 & 0.1038 \\
\hline Barium-133 & 7 & 0.0406 & 0.0032 & 0.0383 & -0.0028 & 0.27 \\
\hline Cerium-144 & 7 & 0.015 & -0.0118 & 0.0267 & -0.0371 & 0.16 \\
\hline Cesium-134 & 7 & 0.0251 & -0.0021 & 0.0275 & -0.009 & 0.19 \\
\hline Cesium-137 & 7 & 6.8981 & 1.28 & 3.8926 & 0.0344 & 23.7 \\
\hline Cobalt-57 & 7 & -0.0036 & -0.0019 & 0.002 & -0.0113 & 0.0018 \\
\hline Cobalt-58 & 7 & -0.002 & -0.0019 & 0.003 & -0.015 & 0.0078 \\
\hline Cobalt-60 & -7 & 0.1271 & 0.0078 & 0.0706 & -0.0025 & 0.4315 \\
\hline Europium-152 & 7 & 0.0714 & 0.0073 & 0.068 & -0.055 & 0.47 \\
\hline Europium-154 & 7 & -0.0755 & -0.03 & 0.0341 & -0.233 & -0.0103 \\
\hline Europium-155 & 7 & 0.0037 & 0 & 0.0197 & -0.095 & 0.0614 \\
\hline Gross alpha & 7 & 18.8817 & 21.125 & 3.0258 & 7.34 & 25.9 \\
\hline Lead-212 & 7 & 1.5318 & 1.7 & 0.2344 & 0.782 & 2.33 \\
\hline Manganese-54 & 7 & 0.024 & 0.025 & 0.0056 & 0.0044 & 0.0476 \\
\hline Neptunium-239 & 7 & 0.4333 & 0.0217 & 0.4447 & -0.091 & 3.1 \\
\hline Nonvolatile beta & 6 & 16.4617 & 15.23 & 4.0606 & 7.04 & 27.7 \\
\hline Plutonium $-239 / 240$ & 9 & 0.0268 & 0.0034 & 0.019 & 0 & 0.171 \\
\hline Plutonium-238 & 9 & 0.0924 & 0.00128 & 0.0498 & 0.0027 & 0.392 \\
\hline Potassium-40 & 7 & 1.3628 & 0.98 & 0.3789 & 0.2999 & 3.09 \\
\hline Promethium-144 & 7 & 0.0015 & 0.0018 & 0.0023 & -0.0074 & 0.0103 \\
\hline Promethium-146 & 7 & 0.0104 & 0.0074 & 0.005 & 0 & 0.038 \\
\hline Ruthenium-106 & 7 & -0.018 & 0.0029 & 0.0255 & -0.165 & 0.0286 \\
\hline Sodium-22 & 7 & 0.108 & 0.0007 & 0.1113 & -0.0025 & 0.7754 \\
\hline Strontium-90 & 7 & 1.2477 & 1.345 & 0.2732 & 0 & 2.28 \\
\hline Thorium-234 & 7 & 1.6366 & 1.27 & 0.5006 & 0.45 & 3.83 \\
\hline Tin-113 & 7 & 0.0018 & -0.0012 & 0.0054 & -0.0136 & 0.0295 \\
\hline Yttrium-88 & 7 & 0.0076 & 0.0052 & 0.0028 & -0.0027 & 0.0156 \\
\hline Zinc-65 & 7 & 0.0321 & 0.0048 & 0.0266 & -0.0111 & 0.19 \\
\hline Zirconium-95 & 7 & 0.0046 & 0.0085 & 0.0088 & -0.0389 & 0.0275 \\
\hline
\end{tabular}


Table 11. General descriptive statistics for radioactive constituents (pCi/g) in L-Lake sediment cores.

\begin{tabular}{|c|c|c|c|c|c|c|}
\hline Isotope & $\mathbf{N}$ & Mean & Median & $\begin{array}{l}\text { Standard } \\
\text { error }\end{array}$ & Minimum & Maximum \\
\hline 1. & 2 & 50 & 20 & 20 & 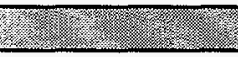 & 40 \\
\hline Actinium-228 & 34 & 1.1016 & 0.993 & 0.1324 & 0.262 & 3.58 \\
\hline Antimony-124 & 34 & 0.0008 & 0.0002 & 0.0008 & -0.0116 & 0.0194 \\
\hline Antimony-125 & 34 & 0.0057 & 0.0025 & 0.0023 & -0.0243 & 0.0464 \\
\hline Barium-133 & 34 & -0.0023 & 0.0005 & 0.0038 & $-0,112$ & 0.035 \\
\hline Cerium-144 & 34 & -0.0038 & -0.0061 & 0.0045 & -0.0531 & 0.101 \\
\hline Cesium-134 & 34 & -0.0021 & 0 & 0.0021 & -0.0631 & 0.0143 \\
\hline Cesium-137 & 34 & 8.6949 & 0.0687 & 3.9186 & 0 & 103 \\
\hline Cobalt-57 & 34 & 0.002 & 0.0009 & 0.0012 & -0.0051 & 0.0351 \\
\hline Cobalt-58 & 34 & -0.0011 & -0.0008 & 0.0005 & -0.0098 & 0.0038 \\
\hline Cobalt-60 & 34 & 0.12 & 0.0017 & 0.0439 & -0.0028 & 0.877 \\
\hline Europium-152 & 34 & -0.0094 & -0.0078 & 0.0026 & -0.0516 & 0.026 \\
\hline Europium-154 & 34 & -0.0003 & -0.003 & 0.0048 & -0.0537 & 0.0734 \\
\hline Europium-155 & 34 & 0.0051 & 0 & 0.0027 & 0 & 0.0744 \\
\hline Gross alpha & 36 & 22.4261 & 15.45 & 3.5366 & 5.27 & 100 \\
\hline Lead-212 & 34 & 1.1411 & 1.045 & 0.1371 & 0.278 & 3.7 \\
\hline Manganese-54 & 34 & 0.0187 & 0.0146 & 0.0025 & -0.0002 & 0.0608 \\
\hline Neptunium-239 & 34 & 0.016 & 0.0049 & 0.0062 & -0.0661 & 0.0882 \\
\hline Nonvolatile beta & 36 & 16.5206 & 9.975 & 3.6916 & 2.57 & 83.7 \\
\hline Plutonium-238 & 33 & 0.0872 & 0.0097 & 0.0415 & -0.0117 & 1.21 \\
\hline Plutonium-239/240 & 32 & 0.0279 & 0.0051 & 0.0103 & 0 & 0.3 \\
\hline Potassium-40 & 34 & 1.5159 & 0.8085 & 0.2811 & 0.278 & 8.41 \\
\hline Promethium-144 & 34 & -0.0001 & -0.0003 & 0.0004 & -0.0051 & 0.0039 \\
\hline Promethium-146 & 34 & 0.0043 & 0.0036 & 0.0012 & -0.0189 & 0.0204 \\
\hline Ruthenium-106 & 34 & 0.0123 & 0.0057 & 0.0045 & -0.0321 & 0.0847 \\
\hline Sodium-22 & 34 & 0.0003 & -0.0002 & 0.0009 & -0.0122 & 0.018 \\
\hline Strontium-90 & 34 & 0.7536 & 0.27 & 0.1387 & -0.353 & 2.18 \\
\hline Thorium-234 & 34 & 1.2823 & 1.11 & 0.1007 & 0.598 & 2.79 \\
\hline $\operatorname{Tin}-113$ & 34 & -0.004 & -0.003 & 0.0015 & -0.0293 & 0.0261 \\
\hline Yttrium-88 & 34 & 0.0021 & 0.0014 & 0.0005 & -0.0019 & 0.0086 \\
\hline Zinc-65 & 34 & 0.0018 & 0.0007 & 0.0017 & -0.019 & 0.0286 \\
\hline Zirconium-95 & 34 & 0.0052 & 0.0005 & 0.0016 & -0.0124 & 0.0338 \\
\hline
\end{tabular}


Table 12. General descriptive statistics for radioactive constituents (pCi/g) in Meyer's Branch sediment cores.

\begin{tabular}{|c|c|c|c|c|c|c|}
\hline Isotope & $\mathbf{N}$ & Mean & Median & $\begin{array}{l}\text { Standard } \\
\text { error }\end{array}$ & Minimum & Maximum \\
\hline 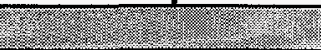 & 7 & 50 & 1) & 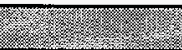 & 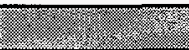 & 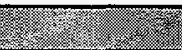 \\
\hline Actinium-228 & 8 & 0.7914 & 0.735 & 0.1326 & 0.39 & 1.5 \\
\hline Antimony-124 & 8 & -0.0006 & -0.0001 & 0.0009 & -0.0035 & 0.0035 \\
\hline Antimony-125 & 8 & 0.0004 & -0.0008 & 0.0016 & -0.0049 & 0.008 \\
\hline Barium-133 & 8 & -0.0024 & -0.0003 & 0.002 & -0.0159 & 0.0018 \\
\hline Cerium-144 & 8 & -0.0073 & -0.0048 & 0.0062 & -0.0449 & 0.0112 \\
\hline Cesium-134 & 8 & -0.0025 & -0.0008 & 0.0023 & -0.0182 & 0.0023 \\
\hline Cesium-137 & 8 & 0.0106 & 0.006 & 0.0049 & -0.0012 & 0.0404 \\
\hline Cobalt-57 & 8 & -0.0006 & -0.0009 & 0.0004 & -0.002 & 0.0014 \\
\hline Cobalt-58 & 8 & -0.0001 & -0.0011 & 0.0013 & -0.0038 & 0.0081 \\
\hline Cobalt-60 & 8 & 0.0006 & -0.0004 & 0.0007 & -0.0014 & 0.0043 \\
\hline Europium-152 & 8 & -0.0052 & -0.0058 & 0.0005 & -0.0068 & -0.0026 \\
\hline Europium-154 & 8 & 0.0025 & 0.0049 & 0.0058 & -0.0267 & 0.0278 \\
\hline Europium-155 & 8 & 0.0034 & 0 & 0.0023 & 0 & 0.0159 \\
\hline Gross alpha & 7 & 14.4614 & 11.4 & 3.3761 & 5.4 & 28.7 \\
\hline Lead-212 & 8 & 0.8303 & 0.764 & 0.1459 & 0.365 & 1.6 \\
\hline Manganese-54 & 8 & 0.0112 & 0.0086 & 0.0033 & 0 & 0.0312 \\
\hline Neptunium-239 & 8 & -0.0029 & -0.0085 & 0.0037 & -0.0118 & 0.0153 \\
\hline Nonvolatile beta & 7 & 7.6343 & 6.51 & 1.6436 & 3.25 & 15.7 \\
\hline Plutonium-238 & 8 & 0.0006 & -0.0008 & 0.0015 & -0.0044 & 0.0066 \\
\hline Plutonium-239/240 & 7 & 0.0009 & 0.0007 & 0.0005 & -0.0013 & 0.0022 \\
\hline Potassium-40 & 8 & 0.9366 & 0.786 & 0.2795 & 0.136 & 2.34 \\
\hline Promethium-144 & 8 & -0.0007 & -0.0005 & 0.0009 & -0.0042 & 0.004 \\
\hline Promethium-146 & 8 & 0.0025 & 0.0016 & 0.0009 & 0 & 0.007 \\
\hline Ruthenium-106 & 8 & -0.0054 & -0.0099 & 0.0058 & -0.0221 & 0.0296 \\
\hline Sodium-22 & 8 & -0.0008 & -0.0015 & 0.0006 & -0.0026 & 0.002 \\
\hline Strontium-90 & 7 & 0.6354 & nd & nd & -0.225 & 2.54 \\
\hline Thorium-234 & 8 & 0.9224 & 0.6855 & 0.1914 & 0.312 & 1.86 \\
\hline Tin-113 & 8 & 0.0003 & 0.0004 & 0.0008 & -0.0029 & 0.0038 \\
\hline Yttrium-88 & 8 & 0.0025 & 0.0022 & 0.0009 & -0.0006 & 0.0066 \\
\hline Zinc-65 & 8 & -0.0014 & -0.0039 & 0.0032 & -0.3124 & 0.0158 \\
\hline Zirconium-95 & 8 & 0.0051 & 0.0024 & 0.0022 & -0.0007 & 0.015 \\
\hline
\end{tabular}


WSRC-TR-96-0238

Table 13. General descriptive statistics for radioactive constituents (pCi/g) in Mill Creek sediment cores.

\begin{tabular}{|c|c|c|c|c|c|c|}
\hline Isotope & $\mathbf{N}$ & Mean & Median & $\begin{array}{l}\text { Standard } \\
\text { error }\end{array}$ & Minimum & Maximum \\
\hline (3) & 5 & $x^{2}=2$ & 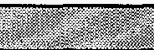 & 2 & 26. & 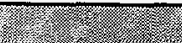 \\
\hline Actinium-228 & 5 & 3.304 & 1.53 & 1.5851 & 0.62 & 9.22 \\
\hline Antimony-124 & 5 & 0.0017 & 0.0026 & 0.001 & -0.0022 & 0.0036 \\
\hline Antimony-125 & 5 & 0.0032 & -0.0003 & 0.0037 & -0.0035 & 0.0152 \\
\hline Barium-133 & 5 & -0.0054 & 0.0014 & 0.009 & -0.0407 & 0.0095 \\
\hline Cerium-144 & 5 & -0.0318 & -0.0165 & 0.0196 & -0.107 & 0.0002 \\
\hline Cesium-134 & 5 & 0.0009 & -0.0017 & 0.0033 & -0.0043 & 0.014 \\
\hline Cesium-137 & 5 & 0.0252 & 0.0068 & 0.0195 & -0.002 & 0.102 \\
\hline Cobalt-57 & 5 & 0.0011 & 0 & 0.0021 & -0.0025 & 0.0092 \\
\hline Cobalt-58 & 5 & -0.0043 & 0.0037 & 0.0029 & -0.0144 & 0.0019 \\
\hline Cobalt-60 & 5 & -0.0017 & -0.0024 & 0.0008 & -0.0037 & 0.0006 \\
\hline Europium-152 & 5 & -0.0231 & -0.0077 & 0.0178 & -0.0935 & 0.0033 \\
\hline Europium-154 & 5 & -0.0083 & 0.0078 & 0.0145 & -0.0598 & 0.021 \\
\hline Gross alpha & 5 & 41.42 & 24.3 & 14.6086 & 10.8 & 89.5 \\
\hline Lead-212 & 5 & 3.5492 & 1.62 & 1.7268 & 0.596 & 10 \\
\hline Manganese-54 & 5 & 0.0538 & 0.0243 & 0.0258 & 0.0086 & 0.149 \\
\hline Neptunium-239 & 5 & -0.0004 & 0 & 0.0075 & -0.0162 & 0.0268 \\
\hline Nonvolatile beta & 5 & 21.39 & 10.8 & 7.938 & 7.04 & 46.1 \\
\hline Plutonium-238 & 6 & 0.0043 & 0 & 0.0055 & -0.0109 & 0.0278 \\
\hline Plutonium-239/240 & 5 & 0.0074 & 0 & 0.0074 & -0.0021 & 0.0369 \\
\hline Potassium -40 & 5 & 1.1866 & 0.679 & 0.5758 & 0 & 3.29 \\
\hline Promethium-144 & 5 & 0.0017 & 0.0033 & 0.0016 & -0.0034 & 0.005 \\
\hline Promethium-146 & 5 & 0.0037 & 0.0045 & 0.0016 & 0 & 0.0078 \\
\hline Ruthenium-106 & 5 & 0.0004 & 0.0117 & 0.0161 & -0.0514 & 0.0365 \\
\hline Sodium-22 & 5 & 0 & 0.0012 & 0.0022 & -0.008 & 0.0049 \\
\hline Strontium-90 & 5 & -0.0573 & -0.0193 & 0.0584 & -0.21 & 0.0744 \\
\hline Thorium-234 & 5 & 1.9646 & 1.66 & 0.5626 & 0.743 & 3.82 \\
\hline Tin-113 & 5 & -0.004 & 0.0003 & 0.0049 & -0.0231 & 0.0031 \\
\hline Yttrium-88 & 5 & 0.0061 & 0.0043 & 0.0034 & -0.0014 & 0.0166 \\
\hline Zinc-65 & 5 & 0.0014 & 0 & 0.0044 & -0.0073 & 0.0173 \\
\hline Zirconium-95 & 5 & 0.0018 & 0 & 0.0018 & 0 & 0.0089 \\
\hline
\end{tabular}


Table 14. General descriptive statistics for radioactive concentrations (pCi/g) in Tinker Creek sediment cores.

\begin{tabular}{|c|c|c|c|c|c|c|}
\hline Isotope & $\mathbf{N}$ & Mean & Median & $\begin{array}{l}\text { Standard } \\
\text { error }\end{array}$ & Minimum & Maximum \\
\hline 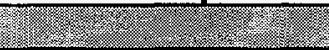 & 2 & 20 & 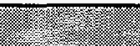 & 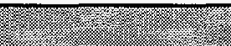 & 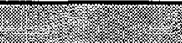 & \\
\hline Actinium-228 & 4 & 1.5703 & 0.9055 & 0.8602 & 0.35 & 4.12 \\
\hline Antimony-124 & 4 & 0.0022 & 0.0018 & 0.0013 & -0.0003 & 0.0055 \\
\hline Antimony-125 & 4 & 0.007 & 0.0039 & 0.0045 & 0.0005 & 0.0197 \\
\hline Barium-133 & 4 & 0.0014 & 0.0017 & 0.002 & -0.0032 & 0.0055 \\
\hline Cerium-144 & 4 & -0.0045 & -0.0065 & 0.0067 & -0.0186 & 0.0136 \\
\hline Cesium-134 & 4 & 0.0019 & 0.0019 & 0.0004 & 0.0011 & 0.003 \\
\hline Cesium-137 & 4 & 0.0016 & 0.0013 & 0.0032 & -0.0055 & 0.0093 \\
\hline Cobalt-57 & 4 & 0.0007 & 0.0008 & 0.0003 & 0 & 0.0015 \\
\hline Cobalt-58 & 4 & -0.0026 & -0.0013 & 0.0018 & -0.0078 & -0.0001 \\
\hline Cobalt-60 & 4 & 0 & 0.0005 & 0.0008 & -0.0029 & 0.0013 \\
\hline Europium-152 & 4 & -0.0196 & -0.0181 & 0.005 & -0.0332 & -0.0091 \\
\hline Europium-154 & 4 & 0.0007 & -0.008 & 0.012 & -0.0162 & 0.0349 \\
\hline Gross alpha & 4 & 40.88 & 8.525 & 34.4653 & 2.47 & 144 \\
\hline Lead-212 & 4 & 1.6993 & 0.955 & 0.958 & 0.347 & 4.54 \\
\hline Manganese-54 & 4 & 0.0281 & 0.0175 & 0.0128 & 0.0111 & 0.0662 \\
\hline Neptunium-239 & 4 & 0.0494 & 0.0002 & 0.0505 & -0.0037 & 0.201 \\
\hline Nonvolatile beta & 4 & 20.8 & 8.945 & 14.2551 & 2.61 & 62.7 \\
\hline Plutonium-238 & 4 & 0.0046 & 0.007 & 0.0059 & -0.011 & 0.0153 \\
\hline Plutonium-239/240 & 4 & 0.0007 & 0.001 & 0.0004 & -0.0006 & 0.0013 \\
\hline Potassium-40 & 4 & 2.8185 & 2.3815 & 1.4243 & 0.191 & 6.32 \\
\hline Promethium-144 & 4 & 0.0003 & 0.0002 & 0.0009 & -0.0018 & 0.0027 \\
\hline Promethium-146 & 4 & 0.0024 & 0.0021 & 0.0011 & 0 & 0.0053 \\
\hline Ruthenium-106 & 4 & -0.0041 & 0 & 0.0047 & -0.0182 & 0.0017 \\
\hline Sodium-22 & 4 & -0.002 & -0.0014 & 0.0013 & -0.0056 & 0.0003 \\
\hline Strontium-90 & 4 & 0.0614 & 0.0403 & 0.099 & -0.129 & 0.294 \\
\hline Thorium-234 & 4 & 1.2803 & 1.405 & 0.4137 & 0.181 & 2.13 \\
\hline Tin-113 & 4 & -0.0059 & -0.0038 & 0.0035 & -0.0156 & -0.0002 \\
\hline Yttrium-88 & 4 & 0.0009 & 0.0003 & 0.0011 & -0.0009 & 0.0037 \\
\hline Zinc-65 & 4 & 0.0004 & -0.0008 & 0.0057 & -0.012 & 0.0153 \\
\hline Zirconium-95 & $\overline{4}$ & 0.0007 & 0.0005 & 0.0004 & 0 & 0.0017 \\
\hline
\end{tabular}


WSRC-TR-96-0238

Table 15. General descriptive statistics for radioactive constituents (pCi/g) in Lake Marion sediment cores.

\begin{tabular}{|c|c|c|c|c|c|c|}
\hline Isotope & $\mathbf{N}$ & Mean & Median & $\begin{array}{l}\text { Standard } \\
\text { error }\end{array}$ & Minimum & Maximum \\
\hline 80 & 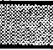 & 2. & s. & $x_{7}$ & 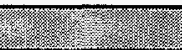 & 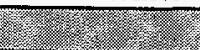 \\
\hline Actinium-228 & 4 & 0.9993 & 0.9405 & 0.2318 & 0.596 & 1.52 \\
\hline Antimony-124 & 4 & 0.0005 & 0.0001 & 0.0008 & -0.0009 & 0.0026 \\
\hline Antimony-125 & 4 & 0.0024 & 0.0011 & 0.0035 & -0.0046 & 0.0121 \\
\hline Barium-133 & 4 & -0.0005 & -0.0004 & 0.0002 & -0.0011 & -0.0001 \\
\hline Cerium-144 & 4 & 0.0015 & 0.0002 & 0.0019 & -0.0014 & 0.007 \\
\hline Cesium-134 & 4 & 0.0008 & 0 & 0.001 & -0.0005 & 0.0038 \\
\hline Cesium-137 & 4 & 0.0026 & 0.0006 & 0.0034 & -0.0028 & 0.0119 \\
\hline Cobalt-57 & 4 & -0.0003 & -0.0005 & 0.0005 & -0.0011 & 0.001 \\
\hline Cobalt-58 & 4 & -0.0002 & -0.0002 & 0.0016 & -0.0042 & 0.0038 \\
\hline Cobalt-60 & 4 & -0.0008 & -0.0012 & 0.0011 & -0.0029 & 0.002 \\
\hline Europium-152 & 4 & -0.0048 & -0.0027 & 0.0057 & -0.0205 & 0.0065 \\
\hline Europium-154 & 4 & -0.0259 & -0.0171 & 0.0138 & -0.0658 & -0.0035 \\
\hline Gross alpha & 4 & 20.85 & 17.3 & 4.7654 & 14 & 34.8 \\
\hline Lead-212 & 4 & 1.071 & 0.9935 & 0.253 & 0.627 & 1.67 \\
\hline Manganese-54 & 4 & 0.019 & 0.0181 & 0.0039 & 0.0106 & 0.029 \\
\hline Neptunium-239 & 4 & -0.0072 & -0.0041 & 0.008 & -0.029 & 0.0084 \\
\hline Nonvolatile beta & 4 & 23.225 & 23.55 & 2.2092 & 17.8 & 28 \\
\hline Plutonium-238 & 4 & -0.0176 & -0.0044 & 0.0167 & -0.0672 & 0.0055 \\
\hline Plutonium-239/240 & 4 & -0.0021 & 0 & 0.0037 & -0.0127 & 0.0044 \\
\hline Potassium-40 & 4 & 7.4375 & 7.42 & 1.7053 & 3.71 & 0.0187 \\
\hline Promethium-144 & 4 & 0.0021 & 0.0024 & 0.0017 & -0.0021 & 0.0056 \\
\hline Promethium-146 & 4 & 0.0017 & 0.0003 & 0.0016 & 0 & 0.0064 \\
\hline Ruthenium-106 & 4 & 0.0138 & 0.0154 & 0.0089 & -0.0071 & 0.0316 \\
\hline Sodium-22 & 4 & -0.0008 & -0.0006 & 0.0019 & -0.0057 & 0.0036 \\
\hline Strontium-90 & 4 & -0.0921 & -0.0852 & 0.1478 & -0.461 & 0.263 \\
\hline Thorium-234 & 4 & 1.0502 & 0.8815 & 0.2415 & 0.688 & 1.75 \\
\hline Tin-113 & 4 & -0.001 & 0.0001 & 0.003 & -0.0092 & 0.0052 \\
\hline Yttrium-88 & 4 & 0.0016 & 0.002 & 0.0006 & -0.0001 & 0.0025 \\
\hline Zinc-65 & 4 & 0.0023 & 0.0027 & 0.0023 & -0.003 & 0.0058 \\
\hline Zirconium-95 & 4 & 0.0062 & 0.0063 & 0.0026 & 0 & 0.0121 \\
\hline
\end{tabular}




\subsubsection{Cesium-137}

The mean volume-weighted cesium-137 concentration for all Par Pond cores was 0.98 picoCuries per gram ([pCi/g] range: background to $11.5 \mathrm{pCi} / \mathrm{g}$; Table 9 ).

The mean volume-weighted cesium-137 concentration for all L-Lake cores was $8.69 \mathrm{pCi} / \mathrm{g}$ (range: background to $103 \mathrm{pCi} / \mathrm{g}$; Table 11 ).

The mean volume-weighted cesium-137 concentration for all background cores was $0.01 \mathrm{pCi} / \mathrm{g}$ (range: background to $0.102 \mathrm{pCi} / \mathrm{g}$; Tables $12-15$ ).

\subsubsection{Plutonium-238}

The mean volume-weighted plutonium-238 concentration for all Par Pond cores was $0.02 \mathrm{pCi} / \mathrm{g}$ (range: background to $0.39 \mathrm{pCi} / \mathrm{g}$; Table 9).

The mean volume-weighted plutonium-238 concentration for all L-Lake cores was $0.09 \mathrm{pCi} / \mathrm{g}$ (range: background to $1.21 \mathrm{pCi} / \mathrm{g}$; Table 11 ).

The mean volume-weighted plutonium-238 concentration for all background cores was background (Tables 12-15).

\subsubsection{Plutonium-239/240}

The mean volume-weighted plutonium-239/240 concentration for all L-Lake cores was $0.03 \mathrm{pCi} / \mathrm{g}$ (range: background to $0.3 \mathrm{pCi} / \mathrm{g}$; Table 11 ).

The mean volume-weighted plutonium-239/240 concentration for all background cores was background (Tables 12-15).

\subsubsection{Cobalt- 60}

The mean volume-weighted cobalt- 60 concentration for all L-Lake cores was $0.12 \mathrm{pCi} / \mathrm{g}$ (range: background to $0.88 \mathrm{pCi} / \mathrm{g}$; Table 11 ).

The mean volume-weighted cobalt- 60 concentration for all background cores was background (Tables 12-15).

\subsubsection{Strontium-90}

The mean volume-weighted strontium- 90 concentration for all L-Lake cores was $0.75 \mathrm{pCi} / \mathrm{g}$ (range: background to $2.18 \mathrm{pCi} / \mathrm{g}$; Table 11 ).

The mean volume-weighted strontium- 90 concentration for all background cores was $0.14 \mathrm{pCi} / \mathrm{g}$ (range: background to 2.54; Tables 12-15). 


\subsubsection{Zirconium-95}

The mean volume-weighted zirconium-95 concentration for all Par Pond cores was $0.015 \mathrm{pCi} / \mathrm{g}$ (range: background to $0.07 \mathrm{pCi} / \mathrm{g}$; Table 9 ).

The mean volume-weighted zirconium-95 concentration for all background cores was background (Tables 12-15).

\subsection{Summary}

Sediment cores from shallow and deep water locations in Par Pond, Pond C, and L Lake were collected and analyzed in 1995 for radioactive and nonradioactive constituents. This core analysis was conducted to develop a defensible characterization of contaminants found in the sediments of Par Pond, Pond C, and L Lake.

Mercury was the only nonradiological constituent with a nonestimated result that was detected above the EPA Region IV potential contaminants of concern screening criteria. It was detected at a depth of 1.0-2.0 feet at one location in L Lake.

Cesium-137, promethium-146, plutonium-238, and zirconium-95 had significantly higher concentrations in Par Pond sediments than in sediments from the reference sites. Cobalt-60, cesium137 , plutonium-238, plutonium-239/240, and strontium- 90 had significantly higher concentrations in L-Lake sediments than sediments from the reference sites. 


\subsection{References}

EPA (U.S. Environmental Protection Agency). 1995. Supplemental Guidance to RAGS: Region IV Bulletins, Ecological Risk Assessment. U.S. Environmental Protection Agency, Region IV Waste Management Division. Atlanta, GA.

Looney, B. B., M. Ramdeen, J. Pickett, V. Rogers, P. A. Shirley, and M. T. Scott. 1989.

Geochemical and Physical Properties of Soils and Shallow Sediments at the Savannah River Plant (a). Savannah River Laboratory. E.I. du Pont de Nemours and Co., Aiken, SC. 


\section{Appendix $A$}

Sample Identification Key for Analytical Results

\begin{tabular}{|c|c|c|c|}
\hline Sample ID & Location & Sample ID & Location \\
\hline 20 & $x-2=2$ & 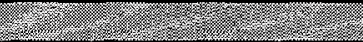 & 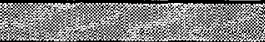 \\
\hline PPSC-FB-01C & Field Blank & PPSC-SED21-(01-03) & Meyer's Branch \\
\hline PPSC-FB-02C & Field Blank & PPSC-SED22-(01-04) & Meyer's Branch \\
\hline PPSC-FB-03C & Field Blank & PPSC-SED23-(01-05) & Mill Creek \\
\hline PPSC-FB-05C & Field Blank & PPSC-SED24-(01-04) & Tinker Creek \\
\hline PPSC-SED01-(01-03) & Par Pond & PPSC-SED25-(01-04) & Lake Marion \\
\hline PPSC-SED02-(01-05) & Par Pond & PPSC-SED26-01A 1 & Lake Marion \\
\hline PPSC-SED03-(01-04) & Par Pond & PPSC-SED26-02D1 & Lake Marion \\
\hline PPSC-SED04-(01-04) ${ }^{1}$ & Par Pond & PPSC-SED26-03A & Lake Marion \\
\hline PPSC-SED05-(01-03) & Par Pond & PPSC-SED27-01D1 & Par Pond \\
\hline PPSC-SED06-(01-04) & Par Pond & PPSC-SED27-02A 1 & Par Pond \\
\hline PPSC-SED07-(01-04) & Par Pond & PPSC-SED27-03D 1 & Par Pond \\
\hline PPSC-SED08-(01-03) & Par Pond & PPSC-SED27-04A 1 & Par Pond \\
\hline PPSC-SED09-(01-03) ${ }^{1}$ & Par Pond & PPSC-SED28-01A 1 & Pond C \\
\hline PPSC-SED10-(01-05) & Par Pond & PPSC-SED28-02D 1 & Pond C \\
\hline PPSC-SED11-(01-03) & Pond $\mathrm{C}$ & PPSC-SED28-03A ${ }^{1}$ & Pond C \\
\hline PPSC-SED12-(01-03) ${ }^{1}$ & Pond C & PPSC-TB-(01B-09B) & Trip Blank \\
\hline PPSC-SED13-(01-04) & L Lake & PPSC-TB-(15B-16B) & Trip Blank \\
\hline PPSC-SED14-(01-03) & L Lake & PPSC-TB-(15B-16B) & Trip Blank \\
\hline PPSC-SED15-(01-05) & L Lake & & \\
\hline PPSC-SED16-(01-05) & L Lake & & \\
\hline PPSC-SED17-(01-04) & L Lake & & \\
\hline PPSC-SED18-(01-03) & L Lake & & \\
\hline PPSC-SED19-(01-05) & L Lake & & \\
\hline PPSC-SED20-(01-03) & L Lake & & \\
\hline
\end{tabular}

1 Four cores were taken at these locations to include duplicates and splits. 


\section{Appendix $B$}

Analyte List

\begin{tabular}{|c|c|c|c|c|}
\hline Location & Sample ID & Core segment & Sample locations & Analyte code ${ }^{1}$ \\
\hline 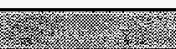 & 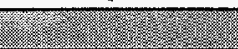 & 20 & 0 & 3. \\
\hline \multirow[t]{41}{*}{ Par Pond } & PPSC-SED01 & 01 & Intake Arm & $1,2,3$ \\
\hline & PPSC-SED01 & 02 & Intake Arm & $1,2,3$ \\
\hline & PPSC-SED01 & 03 & Intake Arm & $1,2,3$ \\
\hline & PPSC-SED01 & 04 & Intake Arm & $1,2,3$ \\
\hline & PPSC-SED01 & 05 & Intake Arm & $1,2,3$ \\
\hline & PPSC-SED02 & 01 & Intake Arm & $0,1,2$ \\
\hline & PPSC-SED02 & 02 & Intake Arm & $0,1,2$ \\
\hline & PPSC-SED02 & 03 & Intake Arm & $0,1,2$ \\
\hline & PPSC-SED02 & 04 & Intake Arm & $0,1,2$ \\
\hline & PPSC-SED02 & 05 & Intake Arm & $0,1,2$ \\
\hline & PPSC-SED03 & 01 & Cold Dam & $0,1,2$ \\
\hline & PPSC-SED03 & 02 & Cold Dam & $0,1,2$ \\
\hline & PPSC-SED03 & 03 & Cold Dam & $0,1,2$ \\
\hline & PPSC-SED03 & 04 & Cold Dam & $0,1,2$ \\
\hline & PPSC-SED03 & 05 & Cold Dam & $0,1,2$ \\
\hline & PPSC-SED04 & 01 & Cold Dam & $1,2,3$ \\
\hline & PPSC-SED04 & 02 & Cold Dam & $1,2,3$ \\
\hline & PPSC-SED04 & 03 & Cold Dam & $1,2,3$ \\
\hline & PPSC-SED04 & 04 & Cold Dam & $1,2,3$ \\
\hline & PPSC-SED04 & 05 & Cold Dam & $1,2,3$ \\
\hline & PPSC-SED05 & 01 & Cold Dam & $0,1,2$ \\
\hline & PPSC-SED05 & 02 & Cold Dam & $0,1,2$ \\
\hline & PPSC-SED05 & 03 & Cold Dam & $0,1,2$ \\
\hline & PPSC-SED05 & 04 & Cold Dam & $0,1,2$ \\
\hline & PPSC-SED05 & 05 & Cold Dam & $0,1,2$ \\
\hline & PPSC-SED06 & 01 & Cold Dam & $0,1,2$ \\
\hline & PPSC-SED06 & 02 & Cold Dam & $0,1,2$ \\
\hline & PPSC-SED06 & 03 & Cold Dam & $0,1,2$ \\
\hline & PPSC-SED06 & 04 & Cold Dam & $0,1,2$ \\
\hline & PPSC-SED06 & 05 & Cold Dam & $0,1,2$ \\
\hline & PPSC-SED07 & 01 & Cold Dam & $0,1,2$ \\
\hline & $\begin{array}{l}\text { PPSC-SED07 } \\
\end{array}$ & 02 & Cold Dam & $0,1,2$ \\
\hline & PPSC-SED07 & 03 & Cold Dam & $0,1,2$ \\
\hline & PPSC-SED07 & 04 & Cold Dam & $0,1,2$ \\
\hline & PPSC-SED07 & 05 & Cold Dam & $0,1,2$ \\
\hline & PPSC-SED08 & 01 & Hot Dam & $0,1,2$ \\
\hline & PPSC-SED08 & 02 & Hot Dam & $0,1,2$ \\
\hline & PPSC-SED08 & 03 & Hot Dam & $0,1,2$ \\
\hline & PPSC-SED08 & 04 & Hot Dam & $0,1,2$ \\
\hline & PPSC-SED08 & 05 & Hot Dam & $0,1,2$ \\
\hline & PPSC-SED09 & 01 & Hot Dam & $1,2,3$ \\
\hline
\end{tabular}

1 Analyte codes are:

0 - Target Analyte List metals.

1 - Specified analytes (nitrate/nitrite, total organic carbons, organic nitrogen, orthophosphate, total phosphate, chloride, particle size distribution, sulfide, cation exchange capacity).

2 - Radionuclides (gross alpha, nonvolatile beta, gamma pulse height analysis, strontium-90, plutonium series).

3 - Target Compound List with tentatively identified compounds. 
Analyte List (continued)

\begin{tabular}{|c|c|c|c|c|}
\hline Location & Sample ID & Core segment & Sample locations & Analyte code ${ }^{1}$ \\
\hline 3.20 & 3. & $8 x^{2}$ & 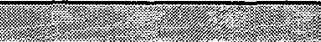 & 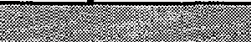 \\
\hline \multirow[t]{24}{*}{$\begin{array}{l}\text { Par Pond } \\
\text { (continued) }\end{array}$} & PPSC-SED09 & 02 & Hot Dam & $1,2,3$ \\
\hline & PPSC-SED09 & 03 & Hot Dam & $1,2,3$ \\
\hline & PPSC-SED09 & 04 & Hot Dam & $1,2,3$ \\
\hline & PPSC-SED09 & 05 & Hot Dam & $1,2,3$ \\
\hline & PPSC-SED10 & 01 & North Arm & $0,1,2$ \\
\hline & PPSC-SED10 & 02 & North Arm & $0,1,2$ \\
\hline & PPSC-SED10 & 03 & North Arm & $0,1,2$ \\
\hline & PPSC-SED10 & 04 & North Arm & $0,1,2$ \\
\hline & PPSC-SED10 & 05 & North Arm & $0,1,2$ \\
\hline & PPSC-SED11 & 01 & North Arm & $1,2,3$ \\
\hline & PPSC-SED11 & $\hat{0} 2$ & North Arm & $1,2,3$ \\
\hline & PPSC-SED11 & 03 & North Arm & $1,2,3$ \\
\hline & PPSC-SED11 & 04 & North Arm & $1,2,3$ \\
\hline & PPSC-SED11 & 05 & North Arm & $1,2,3$ \\
\hline & PPSC-SED12 & 01 & North Arm & $1,2,3$ \\
\hline & PPSC-SED12 & 02 & North Arm & $1,2,3$ \\
\hline & PPSC-SED12 & 03 & North Arm & $1,2,3$ \\
\hline & PPSC-SED12 & 04 & North Arm & $1,2,3$ \\
\hline & PPSC-SED12 & 05 & North Arm & $1,2,3$ \\
\hline & PPSC-SED13 & 01 & North Arm & $0,1,2$ \\
\hline & PPSC-SED13 & 02 & North Arm & $0,1,2$ \\
\hline & PPSC-SED13 & 03 & North Arm & $0,1,2$ \\
\hline & PPSC-SED13 & 04 & North Arm & $0,1,2$ \\
\hline & PPSC-SED13 & 05 & North Arm & $0,1,2$ \\
\hline \multirow[t]{10}{*}{ Pond $\mathrm{C}$} & PPSC-SED14 & 01 & Pond $\mathrm{C}$ & $1,2,3$ \\
\hline & PPSC-SED14 & 02 & Pond $\mathrm{C}$ & $1,2,3$ \\
\hline & PPSC-SED14 & 03 & Pond $\mathrm{C}$ & $1,2,3$ \\
\hline & PPSC-SED14 & 04 & Pond $\mathrm{C}$ & $1,2,3$ \\
\hline & PPSC-SED14 & 05 & Pond $\mathrm{C}$ & $1,2,3$ \\
\hline & PPSC-SED15 & 01 & Pond $\mathrm{C}$ & $0,1,2$ \\
\hline & PPSC-SED15 & 02 & Pond C & $0,1,2$ \\
\hline & PPSC-SED15 & 03 & Pond $\mathrm{C}$ & $0,1,2$ \\
\hline & PPSC-SED15 & 04 & Pond $\mathrm{C}$ & $0,1,2$ \\
\hline & PPSC-SED15 & 05 & Pond $\mathrm{C}$ & $0,1,2$ \\
\hline \multirow[t]{8}{*}{ L Lake } & PPSC-SED16 & 01 & L Lake & $0,1,2$ \\
\hline & PPSC-SED16 & 02 & L Lake & $0,1,2$ \\
\hline & PPSC-SED16 & 03 & L Lake & $0,1,2$ \\
\hline & PPSC-SED16 & 04 & L Lake & $0,1,2$ \\
\hline & PPSC-SED16 & 05 & L Lake & $0,1,2$ \\
\hline & PPSC-SED17 & 01 & L Lake & $1,2,3$ \\
\hline & PPSC-SED17 & 02 & L Lake & $1,2,3$ \\
\hline & PPSC-SED17 & 03 & L Lake & $1,2,3$ \\
\hline
\end{tabular}

Analyte codes are:

0 - Target Analyte List metals.

1 - Specified analytes (nitrate/nitrite, total organic carbons, organic nitrogen, orthophosphate, total phosphate, chloride, particle size distribution, sulfide, cation exchange capacity).

2 - Radionuclides (gross alpha, nonvolatile beta, gamma pulse height analysis, strontium-90, plutonium series).

3 - Target Compound List with tentatively identified compounds. 
Analyte List (continued)

\begin{tabular}{|c|c|c|c|c|}
\hline Location & Sample ID & Core segment & Sample locations & Analyte code $^{1}$ \\
\hline & 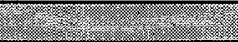 & 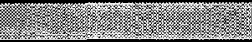 & 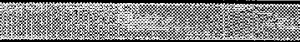 & 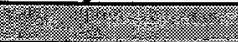 \\
\hline \multirow[t]{17}{*}{$\begin{array}{l}\text { L Lake } \\
\text { (continued) }\end{array}$} & PPSC-SED17 & 04 & L Lake & $1,2,3$ \\
\hline & PPSC-SED17 & 05 & L Lake & $1,2,3$ \\
\hline & PPSC-SED18 & 01 & L Lake & $0,1,2$ \\
\hline & PPSC-SED18 & 02 & L Lake & $0,1,2$ \\
\hline & PPSC-SED18 & 03 & L Lake & $0,1,2$ \\
\hline & PPSC-SED18 & 04 & L Lake & $0,1,2$ \\
\hline & PPSC-SED18 & 05 & L Lake & $0,1,2$ \\
\hline & PPSC-SED19 & 01 & L Lake & $1,2,3$ \\
\hline & PPSC-SED19 & 02 & L Lake & $1,2,3$ \\
\hline & PPSC-SED19 & 03 & L Lake & $1,2,3$ \\
\hline & PPSC-SED19 & 04. & L Lake & $1,2,3$ \\
\hline & PPSC-SED19 & 05 & L Lake & $1,2,3$ \\
\hline & PPSC-SED20 & 01 & L Lake & $0,1,2$ \\
\hline & PPSC-SED20 & 02 & L Lake & $0,1,2$ \\
\hline & PPSC-SED20 & 03 & L Lake & $0,1,2$ \\
\hline & PPSC-SED20 & 04 & L Lake & $0,1,2$ \\
\hline & PPSCSED20 & 05 & L Lake & $0,1,2$ \\
\hline \multirow{10}{*}{ Meyer's Branch } & PPSC-SED21 & 01 & Meyer's Branch & $1,2,3$ \\
\hline & PPSC-SED21 & 02 & Meyer's Branch & $1,2,3$ \\
\hline & PPSC-SED21 & 03 & Meyer's Branch & $1,2,3$ \\
\hline & PPSC-SED21 & 04 & Meyer's Branch & $1,2,3$ \\
\hline & PPSC-SED21 & 05 & Meyer's Branch & $1,2,3$ \\
\hline & PPSC-SED22 & 01 & Meyer's Branch & $1,2,3$ \\
\hline & PPSC-SED22 & 02 & Meyer's Branch & $1,2,3$ \\
\hline & PPSC-SED22 & 03 & Meyer's Branch & $1,2,3$ \\
\hline & PPSC-SED22 & 04 & Meyer's Branch & $1,2,3$ \\
\hline & PPSC-SED22 & 05 & Meyer's Branch & $1,2,3$ \\
\hline \multirow[t]{5}{*}{ Mill Creek } & PPSC-SED23 & 01 & Mill Creek & $1,2,3$ \\
\hline & PPSC-SED23 & 02 & Mill Creek & $1,2,3$ \\
\hline & PPSC-SED23 & 03 & Mill Creek & $1,2,3$ \\
\hline & PPSC-SED23 & 04 & Mill Creek & $1,2,3$ \\
\hline & PPSC-SED23 & 05 & Mill Creek & $1,2,3$ \\
\hline \multirow[t]{5}{*}{ Tinker Creek } & PPSC-SED24 & 01 & Tinker Creek & $1,2,3$ \\
\hline & PPSC SED24 & 02 & Tinker Creek & $1,2,3$ \\
\hline & PPSC-SED24 & 03 & Tinker Creek & $1,2,3$ \\
\hline & PPSC-SED24 & 04 & Tinker Creek & $1,2,3$ \\
\hline & PPSC- SED24 & 05 & Tinker Creek & $1,2,3$ \\
\hline \multirow[t]{5}{*}{ Lake Marion } & PPSC-SED25 & 01 & Lake Marion & $1,2,3$ \\
\hline & PPSC-SED25 & 02 & Lake Marion & $1,2,3$ \\
\hline & PPSC-SED25 & 03 & Lake Marion & $1,2,3$ \\
\hline & PPSC-SED25 & 04 & Lake Marion & $1,2,3$ \\
\hline & PPSC-SED25 & 05 & Lake Marion & $1,2,3$ \\
\hline
\end{tabular}

${ }^{1}$ Analyte codes are:

0 - Target Analyte List metals.

1 - Specified analyses (nitrate/nitrite, total organic carbons, organic nitrogen, orthophosphate, total phosphate, chloride, particle size distribution, sulfide, cation exchange capacity).

2 - Radionuclides (gross alpha, nonvolatile beta, gamma pulse height analysis, strontium-90, plutonium series).

3 - Target Compound List with tentatively identified compounds. 